\title{
HISTORICKÉ PRÁVNÍ INFORMACE A JEJICH DATABÁZOVÉ ZPŘÍSTUPNĚNÍ (VÝCHODISKA, OBECNÉ OTÁZKY A PŘÍPADOVÁ STUDIE)
} JAN KOBER, JÁN MATEJKA, PETR AUBRECHT, DAVID BRŮHA ${ }^{1}$

\begin{abstract}
ABSTRAKT
Článek Historické právní informace a jejich databázové zpřistupnění zkoumá zpř́stupňování výrazně specifického druhu právních informací - historických právních informací. $V$ své první části se článek zabývá všeobecnými otázkami zpř́stupňování historických právních informací a nakládání s nimi. Druhá část popisuje současnou českou situaci a zmiňuje současné praktické obtíže. Třetí část článku přináší kritický přehled aktivit, které byly dosud na poli digitalizace ve zkoumané oblasti uskutečněny. Čtvrtá část článku tyto projekty sumárně hodnotí a na podkladu tohoto hodnocení formuluje optimální požadavky na podobu dalších aktivit. $Z$ těchto požadavků vychází podoba vytvářeného projektu Národní právní dědictví, stručně popsaná částí pátou. Možnosti systému podrobně popisuje rozsáhlá část šestá o zpưsobech jeho využívání. Část část sedmá pak doplňuje část šestou přiblížením roviny vybraných technických parametrů řešeni systému.
\end{abstract}

\footnotetext{
1 Mgr. Jan Kober, LL.M., Ústav státu a práva AV ČR, v. v. i. E-mail: jan.kober@ilaw.cas.cz; JUDr. Ján Matejka, Ph.D., Ústav státu a práva AV ČR, v. v. i. E-mail: matejka@ilaw.cas.cz; Ing. Petr Aubrecht, Ph.D., Ústav státu a práva AV ČR, v. v. i. E-mail: petr.aubrecht@ilaw.cas.cz; Bc. David Brůha, Ústav státu a práva AV ČR, v. v. i. E-mail: david.bruha@ilaw.cas.cz. Př́íspěvek vznikl z podpory projektu NAKI II. č. DG16P02H035 s názvem Národní právní dědictví (National Legal Heritage), jejíž poskytovatelkou je Česká republika - Ministerstvo kultury.
} 


\title{
KLÍČOVÁ SLOVA
}

Právní historie, Databáze, Digitalizace, Knihovny právnické, Česká republika

\begin{abstract}
The article „Historical Legal Informations and Database Access“ examines the problem of digitalisation of a highly specific type of legal information - historical legal information. In its first part, the article deals with the general issues of access to and handling of historical legal information. The second part describes the current Czech situation and mentions the practical difficulties arising from digitalisation and database availability of historical legal informations. The third part of the article provides a critical overview of the activities that have been undertaken in the field of digitization and of database access. The fourth part of the article summarizes the mentioned projects on the basis of this assessment and formulates optimal requirements for the further activities. These requirements are being implemented the National Legal Heritage Project, briefly described in Part Five. The part six describes the possibilities of the system and the ways of its use. The seventh part then completes the preceding part with selected technical parameters of the system solution.
\end{abstract}

\section{KEYWORDS}

Legal history, Databases, Digitalisation, Legal libraries, Czech Republic

\section{1. ÚVODEM}

Předkládaný článek se zabývá problematikou zpřístupňování výrazně specifického druhu právních informací - právních informací historických. V své první části se článek zaobírá všeobecnějšími otázkami zpřístupňování historických právních informací a nakládání s nimi. Druhá část článku navazuje nastíněním současné zdejší situace a zmiňuje stávající praktické obtíže, jejichž částečná řešení může digitalizace přinést. Třetí část článku přináší kritický přehled aktivit, které byly dosud na poli digitalizace historické právní literatury uskutečněny nebo jsou uskutečňovány. Čtvrtá část článku tyto projekty sumárně hodnotí na podkladu tohoto hodnocení for- 
muluje optimální požadavky na podobu aktivit dalších. Z těchto požadavků se pak snažila vycházet podoba vytvářeného projektu Národní právní dědictví, jehož obsah stručně popisuje část pátá. Možnosti systému podrobně popisuje rozsáhlá část šestá o způsobech jeho využívání. Část sedmá pak doplňuje část šestou přiblížením roviny vybraných technických parametrů řešení systému. ${ }^{2}$

\section{HISTORICKÁ PRÁVNÍ INFORMACE MEZI ZAPADLOSTÍ A DIGITALIZACÍ}

Jakým způsobem přistoupit k historickým právním informacím, ${ }^{3}$ resp. úžeji řečeno, $\mathrm{k}$ historické právní literatuře? Má vůbec smysl ji digitalizovat? Nemůže náhlá dostupnost materiálů, vzniklých $\mathrm{v}$ naprosto odlišné době, vést $\mathrm{k}$ jejich nepatřičnému, účelovému a jejich historicitu a jejich naprosto odlišný společenský kontext ignorujícímu užívání? Není digitalizace staré literatury příslovečným vyhazováním peněz z okna? To jsou jen některé pochybovačné otázky, které si lze klást při přemýšlení nad problémem digitalizace staré právní literatury. Zatímco některé historické právní předpisy nalezly prostor pro své zpřístupňování v elektronické podobě již v projektech druhé poloviny 80. let XX. století, právní literatura naopak po dlouhá léta zůstávala ve stínu pozornosti. Projekt CS Legsys, uskutečňovaný na někdejším Ústavu státu a práva ČSAV, byl vytvořen v letech 1986-87 (v podobě záměru) a zahájen roku $1988 .{ }^{4}$ CS Legsys byl koncipován jako systém soudobého (živého) práva, avšak vlivem snahy, využít databázi zá-

2 Článek využívá teze projektu, nastíněné in KOBER, Jan; MATEJKA, Jan. Právněhistorická databáze Národní právní dědictví. In: SUCHOŽA, J.; HUSÁR, J.; HUČKOVÁ, R. (ed.), Právo, obchod, ekonomika VII. Košice: Univerzita Pavla Jozefa Šafárika, Právnická fakulta, 2017, s. 225 a n.

3 Pojem historické právní informace je opozitem právní informace současné; nepevně vymezený praktický předěl mezi minulým a současným odpovídá obdobnému napětí v oblasti historické vědy. Podstatně vyšší praktický význam nežli střešní pojem historické právní informace mají pojmy historické právní časopisy, historická soudní rozhodnutí, historické právní monografie, atd. $\mathrm{V}$ níže popisovaném projektu se soustřed’ujeme pouze na texty autorskoprávně volné. U celistvých prací (např. monografie) to nečiní obtíž. Složitější je situace u prací skladebných (např. časopisy, pocty, kolektivní knihy). Pokud se v jejich rámci vyskytne kapitola či jiný text dosud autorskoprávně chráněný, nebude tento dílčí text zpř́stupněn až do doby, než tato ochrana pomine. 
roveň k projektu podrobné kvantitativní analýzy vývoje československého právního řádu od roku 1918 (František Novák) pokrýval plošně uvedené období republikánského práva, pro léta 1918-1945 však obsáhl pouze ze sbírky zákonů a nařízení, pro období po roce 1945 zahrnul i některé podzákonné předpisy, např. vydávané v Úředním listě. ${ }^{5}$ Později však přestal být tento systém $\mathrm{v}$ ÚSP AV ČR rozvíjen. Jiným právním informačním systémem, zahrnujícím i historické dokumenty, je systém ASPI (Automatizovaný systém právních informací), vytvářený původně veřejnou rukou. Později byl však proměněn v systém komerční a dostal se do rukou zahraničním investorem vlastněného nakladatelského podniku.

Všechny uvedené systémy se soustředily nebo soustřed’ují primárně na právní předpisy, některé $\mathrm{z}$ nich postupem času a v omezeném rozsahu také na sbírky soudních rozhodnutí. Společným znakem části těchto systémů, které jsou vytvářeny $\mathrm{s}$ pouhým komerčním cílem dosahování zisku pro vlastníka systém provozující obchodní společnosti, je specifické východisko, záležící v tom, že jejich obsahový rozvoj systému je plně podřizen uživatelské poptávce. Rozvoj se tedy soustředí pouze na to, oč je $\mathrm{v}$ té které době v právní praxi, zvláště komerční, zájem. V 90. letech minulého století to byly především právní předpisy, později, $v$ době rychlého vzestupu zájmu praxe o soudní rozhodování, stále více i soudní rozhodnutí a posléze i vybrané tituly aktuální právní literatury, zpravidla právě z nakladatelství, provozující ten který právní informační systém. Čerpání pouze z takové literatury ovšem vytváří obraz, který je nedostačující. ${ }^{6}$ Historická právní literatura je materií pro komerční právní praxi téměř zcela nezajímavou a jen obtížně využitelnou, a proto nikdy nenalezla podstatnější prostor v ko-

4 CVRČEK, F.; DONÁT, J.; NOVÁK, F. Informační systém o čs. právních předpisech - CS Legsys. Právník, 1991, č. 5, s. 456-465. Dále též CVRČEK, F. Právní informatika. Praha; Plzeň: Aleš Čeněk, 2010, ISBN 978-80-87439-00-5, s. 35-38.

5 CVRČEK, F.; DONÁT, J.; NOVÁK, F. Informační systém o čs. právních předpisech - CS Legsys. Právník. Praha: Ústav státu a práva AV ČR, 1991, č. 5, s. 456. ISSN 0231-6625.

${ }^{6}$ Nezahrnuje jiný pohled komentářů a literatury z jiných nakladatelství. Nadto patrně odborně nejdůležitější a nejméně obsahově povrchní časopisy jsou většinou vydávány nekomerčními aktéry (univerzitami, ústavy, odbornými spolky, popřípadě státními úřady). Specifické postavení mají časopisy profesních komor, které se z nejasných příčin svým pojetím orientují na komerční vzory, ač jsou vydávány na nekomeční bázi a nic je k tomu tedy nenutí. 
merčních právních informačních systémech. Naopak pro právní vědu je historická právní literatura mimořádně důležitá: umožňuje stopovat vývoj právních problémů a zpo̊sobů myšlení o nich. Využitelné jsou také pro hlubší studium, zvláště s právněhistorickým prvkem, a dále také pro praxi legislativní a jazykovědnou, jakož i pro hlubší studium vývojových otázek vyššími soudy.

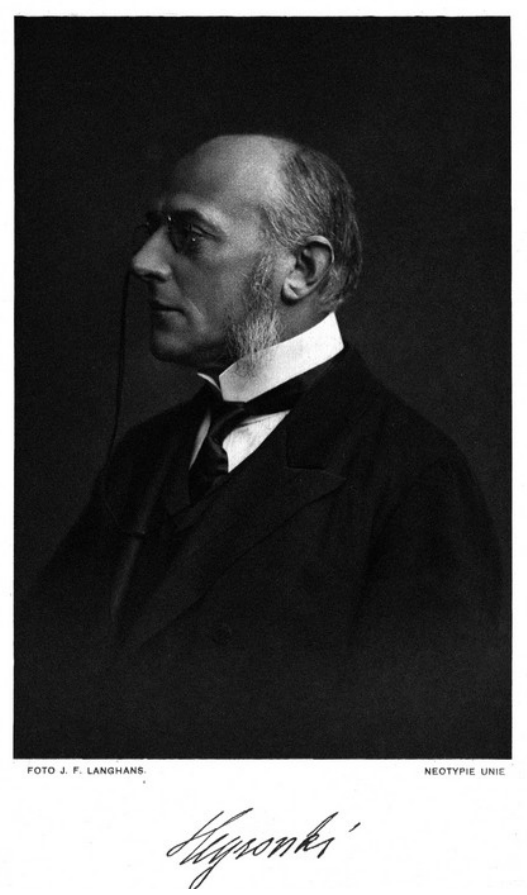

Obr. 1. Vyobrazení Leopolda Heyrovského z pocty, která mu byla věnována. Pocta je jedním z dokumentů, digitalizovaných v projektu Národní právní dědictví.

Informační systém, který by zahrnul historickou právní literaturu a soudní rozhodnutí, by byl vítaným pomocníkem především pro právní historiky, popřípadě pro historiky politických, hospodářských a sociálních dějin. Rovněž pro právní vědce, zabývající se historickým vývojem svých oborů, ale také pro soudce, zvláště pak vyšších soudů, pracovníky ústředních úřadů a ovšem také pro legislativní pracovníky, by měl takový systém nemalou užitečnost. Zpřístupnění historické právní literatury v rám- 
ci informačního systému však v sobě může skrývat i nebezpečí. Ve vztahu k systémům historických právních informací může docházet ze strany nemravných právníků $\mathrm{k}$ velmi snadnému účelovému vyhledávání právních informací, které pak mohou být, vytrženy ze svého odlišného historického kontextu, nekriticky přenášeny do současnosti a užívány např. ve vědomě zavádějící právní argumentaci. Jak upozornil ve svém závažném a v české právní literatuře přelomovém článku Tomáš Richter, nezávislost české právní vědy je dalekosáhle ohrožována do té míry, že podle něj již dnes v komerčně atraktivních oblastech nezávislá právní věda v ČR neexistuje. ${ }^{7}$ Uvedený stav je patrně způsoben zvláště neblahým provázáním komerční právní praxe a právní vědy, resp. personálním pronikáním představitelů advokátní praxe do právní vědy. Stejné nebezpečí, např. účelové užívání historických právních informací s cílem argumentačně ovlivnit soudy ve prospěch klienta anebo obecněji doktrínu ve prospěch určitých výkladových či právněpolitických tendencí, hovících hospodářsky mocným hráčům, z nichž se rekrutuje okruh advokátových klientů, ovšem existuje již nyní, avšak př́itomnost obrovitého korpusu historických právních informací, snadno prohledávatelného jediným kliknutím, tuto cestu zeširoka otevře. Lze ovšem dodat, že např. i soudy budou schopny dohledat zdrojový dokument $\mathrm{v}$ témže historickém informačním systému a zavádějící argumentaci odhalit, byṫ to pro ně samozřejmě bude znamenat nutnost dalšího pracovního úsilí.

7 RICHTER, T. Koho chléb jíš, toho píseň zpívej: konflikty vznikající při propojení právní praxe s právní teorií. Právník, Praha: Ústav státu a práva AV ČR, 2013, č. 2, s. 124-137. ISSN 0231-6625. 


\title{
Sbírka nálezů nejvyššího správního soudu ve věcech administrativních.
}

\author{
Z príkkazu presidia nejuy̌ššiho správního souðu pơ̌ádá \\ JUDr. JOS. V. BOHUSLAV, \\ raða nejvyššiho správniho souðu.
}

Svazek I.

Nálezy z roku $1918-1919$ (č. 1-289).

S dodatkem: Zásaðní usnesení čis. I-XXII.

V PRAZE 1920.

Ređakce v Praze IV., justiění palác. Aoministrace Králouské Vinohraðy Cis. pop. 1234. Nákladem Právnického vyðavatelstuí v Praze, spol. s r. o.

Obr. 2. Sbírka nálezů Nejvyššího správního soudu ve věcech administrativních, pořádaná J. V. Bohuslavem, první svazek za léta 19181919, vydaný roku 1920.

\section{PROČ DIGITALIZOVAT PRÁVNÍ LITERATURU}

\subsection{PŘEHLED PROBLÉMŮ}

Stav českých (a slovenských) odborných právních knihoven ${ }^{8}$ je nedobrý a dostupnost staré právní literatury je velmi neuspokojivá. ${ }^{9}$ Tento stav vzni-

8 Jimi jsou míněny knihovny právnických fakult a knihovny obou ústavů státu a práva. Potažmo k nim lze ještě volně prriřadit knihovny profesních komor, knihovny soudní a knihovny úřední.

9 Výchozí stav jsem již podrobněji popsal v článku zmíněném výše v pozn. č. 2 a na který tímto odkazuji; zde proto podávám pouze stručný vývojový přehled. 
kl souhrou několika vlivů, které se pokusím popsat. Jejich nahlédnutí nám zároveň umožní lépe pochopit, které požadavky může námi připravovaný právní informační systému saturovat a které funkce může uskutečnit. Postupně se budu zabývat výchozí situací v ČR a SR, dále ztrátami na knižních fondech a současnými možnostmi.

\subsection{NEDOSTATKY VLIVEM HISTORICKÉHO VÝVOJE}

Závažným problémem odborných právních knihoven v České republice a ve Slovenské republice je neúplný, někde i jen zcela fragmentární stav jejich staršího, historického knihovního fondu. Zdrojem těchto nedostatků je historický vývoj: u právnických fakult je dodnes určující již sama neblahá situace právnického studia v českých zemích. V první půli XIX. století existovaly v zemích Koruny české pouze dvě právnické fakulty (Praha, Olomouc). Namísto rozvoje pak naopak došlo $\mathrm{k}$ dalšímu omezení, když neoabsolutistický režim Františka Josefa ve svém pronásledování demokratů zrušil v 50. letech olomouckou právnickou fakultu a posléze i celou univerzitu. $\mathrm{V}$ českých zemích tak zůstala fakulta jediná, pražská, v 80. letech rozdělená na českou a německou. Letité úsilí o založení druhé české univerzity v Brně byl za časů habsburské monarchie, Čechům silně nepřející, neúspěšný. Na Slovensku nebyl slovenský jazyk na univerzity připuštěn vůbec a mad’arizačním útlakem byl dokonce vytlačován i ze školství středního. Teprve vyústění světové války a štastný pád habsburské monarchie umožnil dostatečný národní rozvoj Čechů i Slováků a tedy i českého a slovenského právnictví, včetně plnohodnotného rozvoje všech právních profesí a funkcí (např. vysoká státní správa, mezinárodní právo a diplomacie). Republika naplnila staré požadavky a roku 1919 zřídila univerzity v Brně a také v Bratislavě (výuku zahájila až roku 1921), kde vznikla první slovenská právnická fakulta. Knihovny nových fakult byly budovány na zelené louce a stejně jako na obou fakultách pražských, měly podobu knihoven seminárních. Sjednocování do knihoven fakultních přišlo teprve v polovině XX. století. Knihovny dalších fakult, zrrízených ještě později - košické v 70 . letech, olomoucké, plzeňské, banskobystrické a trnavské v 90. letech - bohužel měly a mají historický fond naprosto neucelený, většinou jen nesyste- 
maticky získávaný z darů, odkazů či příležitostných koupí. ${ }^{10}$ Snaha tento fond promyšleně doplňovat směrem $\mathrm{k}$ úplnosti zřejmě nikde neexistovala, nebyla ostatně ani umožněna dostatečným finančním zázemím na promyšlené budování knihovních sbírek.

\subsection{ZTRÁTY NA KNIŽNÍCH FONDECH}

Podstatným prvkem, ovlivňujícím stav právních knihoven v naší republice, byly jednorázové ztráty, které řada knižních fondů utrpěla. Dvě ze čtyř knihoven českých fakult byly poškozeny povodněmi. Zčásti byl nepřímo vinen i nedostatek prostoru, nutící knihovny $\mathrm{k}$ umistování knih do různých podzemních skladů, někdy ne zcela vhodných a vůči vodě nedostatečně zabezpečených. Prvně takto byla postižena část knih olomoucké fakulty při povodních na řece Moravě; o něco později a mnohem ničivěji pak byla poškozena i knihovna pražské fakulty při povodních na Vltavě. Drtivou většinu obrovitých ztrát historického fondu, zčásti tvořenou množstvím unikátní zahraniční literatury, se pochopitelně zacelit nepodařilo. Lze zmínit rovněž ztráty na knižním fondu Ústavu státu a práva AV ČR, vzniklé v době, kdy ústav musel vlivem privatizace $\mathrm{v} 90$. letech XX. století narychlo vyklízet prostory, v nichž měl umístěn rozsáhlý knižní depozitář.

\section{EXISTUJÍCí ZPŘÍSTUPŇOVACÍ SNAHY A POKUSY}

Abychom naznačili kontext projektu, přiblížíme v tomto oddílu některé jiné projekty, které v České republice vznikly. Nejprve se budeme věnovat v pořadí, odpovídajícím době jejich vzniku - projektům zpřístupňujícím určitý právněhistorický obsah, at již coby obsah primární (4.1, 4.3, 4.4, 4.5), anebo jen mezi obsahovými okruhy jinými (4.2). Následně se budeme věnovat českým bibliografickým projektům, opět $\mathrm{v}$ pořadí dle doby jejich vzniku (4.6, 4.7).

10 Podrobněji k situaci knihoven srov. článek zmíněný v pozn. č. 2. 


\subsection{SPOLEČNÁ ČESKO-SLOVENSKÁ DIGITÁLNÍ PARLAMENTNÍ KNIHOVNA}

\subsubsection{CHARAKTERISTIKA}

Nejstarším a velmi záslužným projektem na poli zpřístupňování byla Společná česko-slovenská digitální parlamentní knihovna, uvedená do provozu roku 2002. Byl to projekt ve své době velmi průbojný. Navázal na tradice $\mathrm{z}$ počátků naší republiky, kdy si dal Zdeněk V. Tobolka nemalý úkol: vybudovat téměř z ničeho vzornou parlamentní knihovnu. Reálně byl ovšem tento projekt patrně motivován i nedobrými poměry parlamentní knihovny a špatnou dostupností historických parlamentních tisků prozaicky $\mathrm{z}$ důvodů prostorových (nemožnost uložení $\mathrm{k}$ volnému přístupu $\mathrm{k}$ jejich celým řadám ve studovně) - knihovna parlamentu byla a je od roku 1993 nucena $\mathrm{k}$ existenci v nevyhovujících prostorách. ${ }^{11}$

\subsubsection{PODSTATNÉ NEDOSTATKY}

Zcela zásadní vadou tohoto projektu je odstranění historické paginace a chybějící zpřístupnění předloh. Tento zásah bohužel znemožňuje jakoukoli smysluplnou citaci. Tisky a stenografické protokoly tak v praxi bývají někdy citovány webovou adresou, což je řešení naprosto neštastné a vůči starším citacím s uvedením stránky diskontinuitní. Stejně tak absence paginace činí obtížným dohledání v historických tištěných svazcích (např. v případě blackoutu), jednak vede i k delším citacím, než by vedl jednoduchý odkaz na příslušný svazek a stranu. Z dnešního pohledu je třeba velmi litovat, že nebyla historická paginace zachována a že nebyly zpřístupněny společně s převedeným textem rovněž skeny historických předloh. Skeny však existují a nabízí se tak do budoucna možnost je do databáze spolu s paginací doplnit. Lze doufat, že se tak stane, protože dnes nelze tento zdroj smysluplně citovat. Dalším velkým nedostatkem této digitální knihov-

\footnotetext{
11 Po zániku federace nová Poslanecká sněmovna nepřevzala za své sídlo moderní budovu Federálního shromáždění, dokonale vybavenou a architektonicky cennou (arch. Karel Prager), ale nadále zůstala v prostorově nevyhovujících budovách na Malé Straně, v čemž ji později následoval i Senát. Knihovna zde má jen nepatrný počet studijních míst a příručku, většina jejích fondů musela být uložena jinde.
} 
ny je nemožnost jednoduchého stažení celých textů (například jednotlivých svazků) k práci offline. Převedené texty jsou neštastně rozsekány do tisíců malých html souborů. Vygenerování a stažení celého dokumentu (např. svazku stenoprotokolů) není umožněno.

Habsburkové. Prozatímní správa majetku rodu habsbursko-lotrinského. Č. t. 46. Návrh J. Skorkovského. 5 (26. list. 1918) 76.

Zabaveni jměni býv. panovnického rodu. Č. t. 151. Návrh A. Heinricha. 8 (10. pros. 1918) 154.

Zabaveni jmĕni býv. rak. arciv. Bedřicha Habsburka a použiti ho $\mathrm{k}$ náhradě škod, zpúsobených přislušnikủm $\mathrm{R}$. Čsl. internovánim,

konfinováním a vězněním. Č. t. 277. Návrh dra Bartoška. 14 (9. ledna 1919) 340; zpráva (ústav. výb.) č. t. 2843. 145 (15. dubna

1920) 4281.

Zákaz pobytu ve státě čsl. a nabyti státni přislušnosti v něm. Č. t. 1517. Návrh F. Sise. 72 (16. zárí 1919) 2231; zpráva (ústav. výb.)

Hájek. Komisionelní prohlídky kláštera v Hájku. Dotaz dra Mazance č. 986 . Odpověđ č. 1858. 92 (25. list. 1919) 2744

Haličti uprchlici. Vykázáni jich z R. Čsl. Dotaz J. Nohela č. 1064. Odpověđ̛ č. 1219. 60 (26. června 1919) 1764.

Hardtmuth L. \& C. viz Budějovice.

Obr. 3. Ukázka z rejstř́íku digitalizovaných parlamentních materiálů v Digitálním repozitáři PSP.

\subsection{NĚKTERÉ PRÁVNICKÉ DOKUMENTY V PROJEKTU KRAMERIUS}

\subsubsection{NEDOSTATKY}

Patrně největším a po dlouhá léta neměnným zklamáním na poli české digitalizace je projekt Kramerius. Jeho hostilita vưči potřebám uživatelů je pověstná. Největším nedostatkem je nemožnost rychlého a jednoduchého stahování celých dokumentů pro práci offline. Autor tohoto textu kontaktoval uskutečňovatele projektu Kramerius konstruktivně kritickým dopisem. ${ }^{12}$ Ve vstřícné odpovědi pracovníků projektu Kramerius na e-mail bylo uvedeno, že omezení stahování maximálně 20 stranami je motivováno značnou náročností generování větších textů ze skenů. ${ }^{13} \mathrm{~V}$ následné odpovědi jsem navrhl, aby dokumenty jako celek byly jednou provždy od kaž-

12 E-mail autora týmu projektu Kramerius z 26.06.2017 (archiv autora). 
dého dokumentu automaticky vygenerovány (třeba i ve více kvalitativních a objemově se lišících variantách) v pdf, takto jednou provždy uloženy na serveru a uživateli jednoduše stahovány, ${ }^{14}$ nebot’ značná část uživatelů by preferovala jednorázové stáhnutí celého dokumentu a nikoli generování kousku textu od strany $\mathrm{x}$ do strany $\mathrm{y}$. Osoba, chtějící si vygenerovat jen určité stránky, by tak nadále mohla činit bud' s omezením 20 stran, anebo si stáhnout celý dokument k sobě a již na svém zařízení, bez zátěže serveru Krameria, si z něj dále sama generovat, resp. vyjímat menší části. ${ }^{15} \mathrm{Na}$ tyto náměty jsem již žádnou další odpověd' neobdržel, resp. bylo mi sděleno, že podnět bude přeposlán dalším kolegům. ${ }^{16}$

\subsubsection{DALŠÍ PROBLÉMY}

OCR Krameria, přinejmenším u dříve digitalizovaných dokumentů, je vesměs nekvalitní a postrádá korektury. Vedle toho lze Krameriu vytknout absenci koncepce při volbě toho, co a $\mathrm{v}$ jakém pořadí bude digitalizováno. Ilustrovat to lze např. na denním tisku z období počátků 20. let, kde je, namísto nabízejícího se postupu od největších celostátních deníků (coby historicky a společensky nejdůležitějších) k menším deníkům okresním a různým periodikům zájmovým, došlo $\mathrm{k}$ digitalizaci i některých bezvýznamných lokálních tiskovin, zatímco některé pro historiky meziválečného období klíčové celostátní deníky typu Práva lidu dodnes digitalizovány nebyly. Srovnáváme-li výsledky a uživatelskou vstřícnost Krameria např. s výtečným francouzským projektem Gallica, uskutečňovaným francouzskou Národní knihovnou, s dosti zdařilým projektem bavorským či decentralizovanou, avšak přesto užitečnou digitalizací polskou, nemůžeme než konstatovat značné zklamání.

\footnotetext{
13 „Ohledně limitu pro stahování jsme nuceni s lítostí konstatovat, že důvodem omezení počtu stran $\mathrm{v}$ generovaném PDF je zejména výpočetní náročnost tohoto procesu. Souběh několika požadavků $\mathrm{v}$ jednom okamžiku hrozí zpomalením chodu aplikace, nebo přímo její nedostupností. Proto jsme nuceni na současné infrastruktuře minimalizovat riziko havárie aplikace tímto limitem. Hledáme takové technické řešení, které by nám do budoucna umožnilo limit na stahování navýšit či rovnou zrušit“. Tamtéž.

${ }^{14}$ Stejně tak to správně a jednoduše činí projekt Archive, projekt, který je, navzdory různým nedostatkům, nejvíce orientován na potřeby uživatelů.

15 Tamtéž

16 Tamtéž.
} 


\subsection{PRÁVNICKÁ FAKULTA UNIVERZITY KARLOVY - OCHRANNÁ DIGITALIZACE STARÝCH KNIH}

Rovněž Právnická fakulta Univerzity Karlovy přistoupila k menší digitalizaci a z digitalizovaných dokumentů vytvořila Historickou sbírku knihovny Právnické fakulty UK. ${ }^{17} \mathrm{~V}$ současnosti lze ve sbírce najít 64 dokumentů. Je zde několik starých tisků - Nové právo útrpné a hrdelní krále Josefa I., Constitutio Criminalis Theresiana, Všeobecný řád soudní ( $\mathrm{v}$ schönfeldovském vydání) a dále Koldínova Práva a zrǐ́zení zemská království českého. Ostatní položky tvoří svazky říšské sbírky zákonů (říšského zákoníku) z let 1849 až 1852 a 1860 až 1916 . K samotným textům se nám však nepodařilo dostat, nebot př́stup $\mathrm{k}$ nim (na digitool.is.cuni.cz) nefungoval (po kliknutí na ikonu s nápisem „fulltext“ prohlížeč hlásil, že stránka není dostupná $^{18}$ ). Lze však předpokládat, že se jedná pouze o skeny historické předlohy. Zda systém umožňuje stažení digitalizovaného textu pro práci offline či jeho prohledávání, jsme nemohli zjistit.

\subsection{PRÁVNICKÁ FAKULTA MASARYKOVY UNIVERZITY - DIGITALIZACE MORAVSKÉHO ZEMSKÉHO ZÁKONÍKU A ŘÍŠSKÉHO ZÁKONÍKU}

\subsubsection{ZÁKLADNÍ CHARAKTERISTIKA}

Jiným digitalizačním projektem se stalo zpřístupnění moravské sbírky zákonů a říšského zákoníku aktivitou Právnické fakulty Masarykovy univerzity. Obě digitalizace sdílejí stejný způsob zpřístupnění, záležící v naskenování listů sbírky, v jejich uložení a uveřejnění ve formátu png, $v$ částečném (jen u některých ročníků, viz níže) zpracování metadat v podobě názvů předpisů a jejich zpř́istupnění pomocí rozklikávání jednotlivých let a jednotlivých předpisů. Naopak bohužel nedošlo $\mathrm{k}$ využití skenů pro získání vlastního textu zdrojového dokumentu metodou OCR.

17 PRÁVNICKÁ FAKULTA UNIVERZITY KARLOVY. Historická sbírka knihovny Právnické fakulty UK [online]. [cit. 12.11.2017]. Dostupné z: http://digitool.is.cuni.cz/R/Y2K1NAKRBSHAKP4RHCLK7XKVG4QFCNS485EJDNSMNN98RGIT8U-00097? func $=$ collectionsresult\&collection_id $=2847$

${ }^{18}$ Př́stup byl zkoušen opakovaně ještě i později při úpravách článku, opět bezvýsledně. 


\subsubsection{MODUL MORAVSKÁ SBÍRKA}

Moravská sbírka ${ }^{19}$ pokrývá léta 1848 až 1859, 1871 až 1873 a 1884 až 1919. Pouze část z těchto naskenovaných ročníků je však opatřena i obsahem (metadaty $\mathrm{v}$ podobě názvů právních předpisů, naskenovanými $\mathrm{z}$ indexu jednotlivých svazků). Naopak jiné ročníky (1848-1855, 1857-1859 a 1890-1901) tato metadata postrádají a při vyhledávání se z nich tedy samozřejmě nezobrazují výsledky. Reálně jsou tedy plně - se skeny i metadaty $\mathrm{v}$ podobě názvů předpisů - v současné době zpřístupněny pouze roky 1856, 1871-1873, 1884-1889 a 1902-1919. U ostatních ročníků je nutné hledat ve skenech každého jednotlivého svazku naskenovaný obsah. Proč existuje ve zpo̊sobu zpřístupnění taková nepravidelnost, není zřejmé.

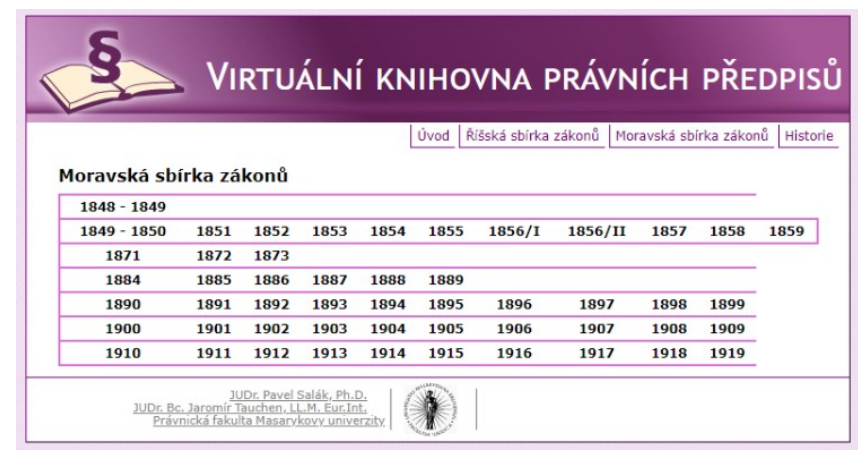

Obr. 4. Základní rozhraní Moravské sbírky zákonů.

Přestože systém nabízí řádek pro vyhledávání (je možné pouze v celém systému a nelze je omezit např. na ročník), ve skutečnosti tato funkce funguje pouze jako vyhledávač v metadatech, nikoli ve vlastních textech předpisů, které $\mathrm{k}$ dispozici nejsou. Lze tedy vyhledávat pouze $\mathrm{v}$ názvech předpisů - v textech proklikávatelného obsahu, ovšem pouze těch ročníků, které metadata mají, tj. 1856, 1871-1873, 1884-1889 a 1902-1919.

19 PRÁVNICKÁ FAKULTA MASARYKOVY UNIVERZITY. Moravská sbírka [online]. [cit. 15.11.2017]. Dostupné na: https://is.muni.cz/do/rect/el/estud/praf/ps09/dlibrary/

web/ms.html 


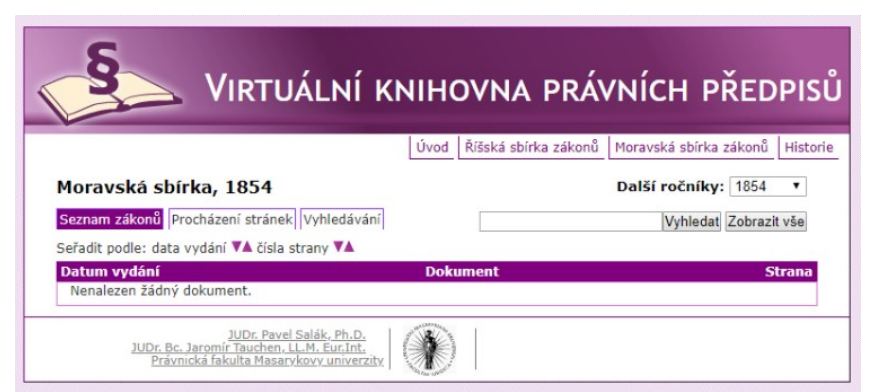

Obr. 5. Příklad ročníku bez metadat (ročník 1854).

\subsubsection{MODUL ŘíŠSKÉHO ZÁKONÍKU}

$\mathrm{O}$ říšském zákoníku ${ }^{20} \mathrm{v}$ zásadě platí to, co bylo uvedeno výše. I v jeho př́ipadě jde o digitalizaci ucelené řady 1849-1918 (chybí však ročníky 18531859 a 1866-1867).

Také zde z nejasné příčiny část ročníků metadata v podobě názvů zákonů má a část nikoli. $\mathrm{V}$ těchto metadatech lze vyhledávat pouze $\mathrm{u}$ ročníků 1851 až 1852, 1860 až 1865, 1868 až 1884, 1895 až 1918. U ostatních lze, stejně jako výše u moravské sbírky, pouze listovat ve skenech. Také ve všem ostatním je zpř́stupnění totožné.

${ }^{20}$ PRÁVNICKÁ FAKULTA MASARYKOVY UNIVERZITY. Říšský zákoník [online]. [cit. 15.11.2017]. Dostupné z: https://is.muni.cz/do/rect/el/estud/praf/ps09/dlibrary/

web/rs.html 


\section{$\S$}

\section{VIRTUÁLNí KNIHOVNA PRÁVNÍCH PŘEDPISŮ}

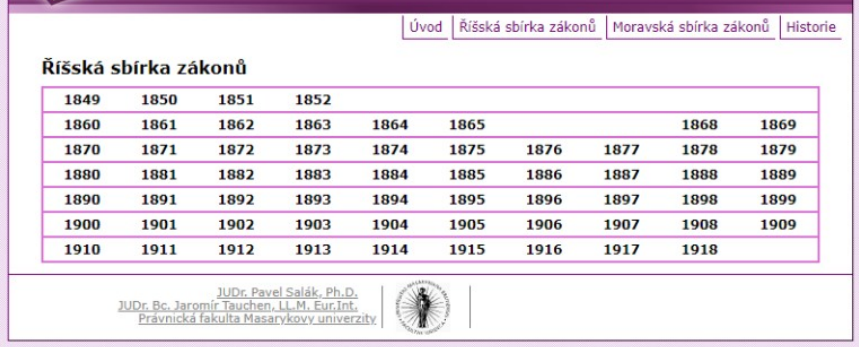

Obr. 6. Základní rozhraní říšské sbírky zákonů.

\subsubsection{NEDOSTATKY SPOLEČNÉ OBĚMA MODULŮM}

Zásadní vadou tohoto systému je značná hostilita vůči uživatelům: není možné ročníky jako celek jednoduše stáhnout v jediném souboru pdf (nebo alespoň komprimovaný archiv jednotlivých obrazových souborů) k užívání offline; stejně tak nelze stahovat ani jednotlivé předpisy. Jedinou možností jak text uložit, je učinit tak samostatně pro každý jednotlivý obrázek (png). Okno zpřístupňuje vždy pouze jedinou stránku skenu. Pro přejití na stránku další je třeba klikat na malou ikonku. Existuje funkce „vytisknout stránku“, vztahující se však právě na jeden sken; chce-li kdo vytisknout dvacetistránkový předpis, musí tak učinit postupným proklikáním a dvacetkrát každou jednotlivou stránku vytisknout (stránka se nadto nevytiskne sama o sobě, ale doplněna záhlavím, zápatím a poutavým vyobrazením rolovacích lišt).

\subsection{PRÁVNICKÁ FAKULTA MASARYKOVY UNIVERZITY - OCHRANNÁ DIGITALIZACE RŮZNÝCH STARÝCH KNIH}

\subsubsection{CHARAKTERISTIKA A HLAVNÍ KLADY PROJEKTU}

Projekt Digitální knihovny Právnické fakulty Masarykovy Univerzity započal roku 2014 a je nyní zpřístupněn pod názvem Digitální knihovna histo- 
rického fondu. ${ }^{21}$ Autoři digitalizace na Právnické fakultě Masarykovy univerzity pochopili, že podstatným požadavkem uživatelů je vedle jiného možnost jednoduše, jedním kliknutím, stáhnout dokument (knihu, ročník časopisu, jednotlivý článek) a uložit si jej k práci offline. Tomuto požadavku, na rozdíl od Krameria, brněnský projekt vyhovuje dokonale, když jednoduché stažení textů umožňuje. Český čtenář, pozorující zahraniční digitalizační úspěchy na straně jedné a zdejší donedávna digitalizační mizerii (hlavně krameriovskou) na straně druhé, je proto hotov hlasitě chválit brněnskou digitalizaci už jen pro to, že tato mu možnost rychlého a jednoduchého stažení celých knih vůbec poskytuje. Chválu za samožrejmost poskytnutou v prostředí plném nesamozřejmosti si brněnský projekt jistě zaslouží: zároveň však nemohou zůstat bez další kritiky některé jeho nedostatky.

\subsubsection{NEDOSTATEK KONCEPCE}

Zásadní vadou je, jak se zdá, bezkoncepčnost digitalizace. Pozorovatel může při prohlížení obsahu databáze $\mathrm{v}$ marné snaze dobrat se kritérií výběru skenovaných děl ustat jedině na tom, že patrně žádná taková kritéria nebyla. Skenováno snad bylo to, co stálo ve skladu seřazeno dle př́rio̊stkových čísel na polici. ${ }^{22}$ Vedle výtečných knih najít lze mezi naskenovaným i práce nepř́ípadné, mnoho knih nemajících vztah k právu ani př́ibuzným oborům (např. Pozdně gotické deskové malîřství v Čechách od Jaroslava Pešiny) či výjimečně i knih nevědeckých (nap̌r. náboženská tématika). Mezi zpřístupněnými díly lze skrze vlastnické značky sledovat mj. sbírku Karla Laštovky, bohatou mj. na slovaka a hungarika (původce působil na bratislavské fakultě). Hodnotným prvkem je také kolekce separátů, metadaty ovšem nijak neuzavřená v jediný celek.

${ }^{21}$ PRÁVNICKÁ FAKULTA MASARYKOVY UNIVERZITY. Digitální knihovna historického fondu [online]. [cit. 15.11.2017]. Dostupné z: https://library.law.muni.cz/content/cs/ezdroje/digitalni-knihovna/

${ }^{22}$ Plošnost zpracování ovšem může mít i jisté klady, např. poskytuje pohled na rozsah a obsah historických seminárních knihoven, ovšem za předpokladu oddělení pozdějších nákupů a darů např. poznámkou v metadatech. 


\subsubsection{NEDOSTATKY VYHLEDÁVÁNÍ A METADAT}

Vyhledávání je umožněno na plnotextové úrovni. Protože však současný způsob zpřístupnění neumožňuje žádný druh přepínání mezi různým zobrazením, nelze text, získaný pomocí OCR kvalitně vizualizovat a prohledávat $\mathrm{v}$ něm - je poskytnut pouze jako součást souborů pdf. Je proto i obtížné plošně zhodnotit kvalitu nebo nekvalitu tohoto OCR. Velkým problémem je samotné nastavení vyhledávání, při kterém se $\mathrm{v}$ defaultní podobě objevuje nemožné množství výsledků, často pochybné nebo chybějící relevance. Vyhledáváme-li např. přesný, uvozovkami uzavřený pojem „mezinárodní právo soukromé“, databáze vyhledá všechny záznamy, v nichž je uvedeno „mezinárodní“ nebo „právo“ nebo „soukromé“. Vyhledávání v databázi je umožněno i na úrovni metadat: hlavním problémem však zůstává mimořádná nekvalita tohoto vyhledávání $\mathrm{v}$ metadatech. Nelze užít běžné vyhledávací syntaxe (např. uvozovek $\mathrm{k}$ nalezení přesného výrazu, značky + , AND, apod.). Také úroveň metadat $\mathrm{u}$ jednotlivých dokumentů je velmi různá. Ještě nejspolehlivějším způsobem, jak se k určité knize dostat, je vyhledávání autoritní, pokud ovšem známe autora.

\subsubsection{NEDOSTATKY VNITŘNÍHO ČLENĚNÍ SBÍRKY}

Digitální knihovna má v současnosti tř̌i základní sbírky, dosti nevhodně zvolené: Historický fond 1801-1918, Historický fond od roku 1919a Osobnosti. První dvě kolekce lze patrně vysvětlit převzetím knihovnických manipulačních kategorií, např. ochranných či z oblasti uložení fondu. Třetí je quasi-sbírkou, vytvořenou poznovu drtivou většinou obsahu $\mathrm{z}$ obou sbírek předešlých, přičleněním děl $\mathrm{k}$ autoritám. Skutečným členěním tak zůstává členění oborové, z nejasné příčiny se opět rozpadající vždy pouze do dvou oddílů (1801-1918, 1919-současnost). Existující oborové kategorie jsou: Právní dějiny, Římské právo, Církevní právo; dále pak Právní teorie, Ústavní právo, Správní právo, Trestní právo, Občanské právo, Obchodní právo, Mezinárodní právo, Národní hospodářství, finanční právo. Velkými kategoriemi jsou zbytkové kategorie nazvané „Ostatní (neprávní fond)“ a „Ostatní (právní fond)“. Mimořádně podivná je absence kategorie 
Pracovního práva, ${ }^{23}$ Rodinného práva a také Civilního procesního práva. Užitá tradiční střešní kategorie občanského práva je problematická jak pojmově, tak i z hlediska funkčního (praktické techniky vyhledávání - je přespř́liš široká). Zcela chybí kategorie Státovědy, což ovšem odráží i její spíše kormutlivé postavení na současných fakultách; chybí bohužel i kategorie Kolizního práva. ${ }^{24}$ Zásadním problémem ve vztahu $\mathrm{k}$ nepřehledné šîri občanského práva je i absence kategorií Věcná práva, Závazkové právo, Dědické právo, Právo osob či Obecné občanské právo. Dosti problematické je i propojení finančního práva s národním hospodářstvím: na místě by byly dvě kategorie samostatné. Kategorie právní teorie by měla být doplněna i o právní filosofii, nebot hranice mezi nimi nejsou historicky podstatné. Užitečná by snad mohla být i kategorie Právní profese a $\mathrm{z}$ hlediska pragmatického i kategorie Mezioborové pocty a sborníky. Chybět by neměla kategorie Personálie. Z kategorie Ostatní by zcela jistě měly dojít některé pro právo zvláště podstatné obory vyčlenění: nabízely by se přinejmenším kategorie Historie, Filosofie, Politická věda, Vnitřní politika, Mezinárodní politika a diplomacie, a také Sociologie či Statistika. Za úvahu by stálo zř́́dit i dodatkovou (k podřazení do jiných kategorií se pouze přimykající) kategorii Historické sbírky, členěnou dále do podsbírek podle vysledovatelných zaniklých sbírek, indikovaných např. vlastnickými značkami (srov. výše zmíněná Sbírka Karla Laštovky ${ }^{25}$ ). Spřežení těchto publikací pospolu by bylo právněhistoricky a ovšem i knihovnicky velmi užitečné a bylo by také výrazem docenění shromažd’ovatelského úsilí jejich původců.

\subsubsection{NEDOSTATKY A DÍLČÍ SHRNUTÍ}

Naopak mimo pozornost autorů zůstaly další požadavky, např́íklad práce $s$ textem. Vedle historické předlohy zde chybí, stejně jako u projektů sbírek,

${ }^{23}$ N. b. na fakultě s velmi významnou katedrou pracovního práva.

24 Často nesmyslně označovaného jako „mezinárodní právo soukromé“. V angloamerickém prostředí je užíván podstatně vhodnější pojem „Conflict of laws“. Kladně lze naopak hodnotit užití názvu kategorie „Mezinárodní právo“ a nikoli, jako se někdy nevhodně a nesmyslně užívá, „Mezinárodní právo veřejné“.

25 Lze dodat, že v názvech sbírek by se neměly objevovat akademické tituly, nebở původci sbírek byli osobami široce známými a záměna s jiným nositelem téhož jména a příjmení v daných souvislostech jistě nehrozí. 
samostatné a volitelné zpřístupnění nejen podoby faksimilové, ale i plnotextové, prohledávatelné a členitelné. Menší vadou spíše technické povahy je i občasná kvalitativní různost skenů: srovnejme např. sken některé z učebnic z 30. let s nekvalitními skeny Heyrovského Systému ve známém 4. vydání z roku 1910. Současná databáze působí dojmem, že byla vytvořena velmi narychlo a ledabyle: neobsahuje informace o projektu (prázdná stránka) ani návod, také „často kladené otázky“ zobrazují prázdnou stránku. Přes uvedené kritické výtky je třeba dodat, že projekt kvalitně splnil, co si předsevzal, totiž chránit starý knižní fond a široce jej zpřístupnit $\mathrm{k}$ užívání. U učebnic a jiných prací, které valně nezastaraly, tedy římskoprávních a právněhistorických, je to široce užitečné především pro studenty. Naopak ve vztahu k ostatním textům může být zpřístupnění přínosem převážně pro právní historiky (např. práce $\mathrm{z}$ oblasti věcného, dědického či procesního práva). Poučeným a trpělivým čtenářům může vedle užitečného stažení plných textů nabídnout při dlouhém přebírání hlušiny řadu radostných a nečekaných překvapení (a posílit tak $\mathrm{v}$ životě vědců prvek dobrodružství), avšak kvalitní nástroje vyhledávání a procházení dosud nemá.

\section{6 ÚSTAV STÁTU A PRÁVA AV ČR - BIBLIOGRAFICKÁ DATABÁZE CLAN}

Na poli bibliografie je nejstarším a nejrozsáhlejším projektem zřejmě Bibliografická databáze CLAN, vytvářená Střediskem vědeckých informací ÚSP AV ČR již od počátku 90. let XX. století. ${ }^{26}$ Databáze zahrnuje bibliografické údaje o článcích většiny (byt bohužel ne všech) českých a slovenských právních časopisů od doby svého vzniku a výběrově i některé články retrospektivně (v současnosti okolo 40 tisíc záznamů). Přidanou hodnotou jsou nejen precizní bibliografické záznamy, vytvářené knihovníky, ale u článků i shrnutí. Velkým kladem je i zahrnutí zpráv z vědeckého života, personálií či recenzí.

${ }^{26}$ ÚSTAV STÁTU A PRÁVA. Databáze [online]. [cit. 22.11.2017]. Dostupné na: https://www.ilaw.cas.cz/sluzby-on-line-knihovna/databaze.html 


\begin{tabular}{|c|c|c|c|}
\hline 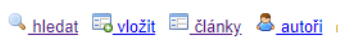 & \multicolumn{2}{|l|}{ kličová slova } & Jan Kober \\
\hline \multirow{2}{*}{\multicolumn{3}{|c|}{$\begin{array}{l}\text { Vyhledávání v názvu článků ročnícich časopisủ } \\
\text { hledat v názvu: }\end{array}$}} & $=0$ \\
\hline & & & Q \\
\hline nalezeno 29 článků pro vybrané & odikum a rok, vypisuji podle id vzestupně: & & \\
\hline id autoři & název článku & $\underline{\text { rok }}$ & akce \\
\hline 477 Kopecký Martin & Reforma územní správy a správní rád & 1991 & 口曰 \\
\hline 2236 Šimek Lubomír & Správní řád a tzv. sankční zákon & 1994 & $\llbracket \square$ \\
\hline 3310 Nèmec Vladimír & Novela správniho řádu, nebo nový správni řád? & 1994 & $\llbracket \sqrt{=0}$ \\
\hline 3697 Průchová Ivana & Ochrana životního prostředí a správní řád & 1996 & $\varphi=0$ \\
\hline 13815 Nedorost Libor & Podklady pro rozhodnutí a dokazování & 2001 & $\square=0$ \\
\hline 16993 Staša Josef & Nový správní řád a stavební právo & 2004 & $\square=0$ \\
\hline 16994 & Zákon 500/2004 Sb.ze dne 24.června 2004 - správní řád. & 2004 & $\square=0$ \\
\hline 17192 Vopálka Vladimír & Nový správní řád- rozsah pủsobnosti a vztahy k jiným právním předpisủm & 2004 & $\square=0$ \\
\hline 17442 Mikule Vladimír & Nový správní raád je konečně na světě & 2004 & $\square=0$ \\
\hline 17873 Kolman Petr & Nový správní rád : Otázka jednacího jazyka & 2005 & $\square=0$ \\
\hline 17923 Vedral Josef & Nový správní řád a územní samospráva & 2005 & $\varphi=0$ \\
\hline 18542 Kolman Petr & Nový správní řád - otázka jednacího jazyka & 2005 & $\square=8$ \\
\hline 18834 Průcha Petr & Správní právo procesní na rozcestí & 2005 & $\square=0$ \\
\hline 19270 Černý Pavel & Nový správní řád (nejen) z pohledu osob dotčených rozhodováním & 2006 & $\square=0$ \\
\hline
\end{tabular}

Obr. 7. Ukázka vyhledávání v databázi CLAN.

Naopak určitým nedostatkem databáze, orientované na články v periodických tiskovinách, je nezahrnutí obsahu poct, sborníků a kolektivních monografií, jakož i monografií jediného autora. Tento nedostatek je však vzhledem ke zvladatelnému počtu uvedených publikací stále ještě bez větších obtíží zpětně doplnitelný. Pro veřejnost je dostupné zjednodušené vyhledávání. $^{27}$ Plné vyhledávání umožňuje kombinované dotazy, procházení podle klíčových slov, po autoritních záznamech, nakladatelích, procházení jednotlivých periodik, apod.

27 ÚSTAV STÁTU A PRÁVA. Databáze CLAN [online]. [cit. 22.11.2017]. Dostupné z: https://data.ilaw.cas.cz/knihovna_vyhledavani.php 


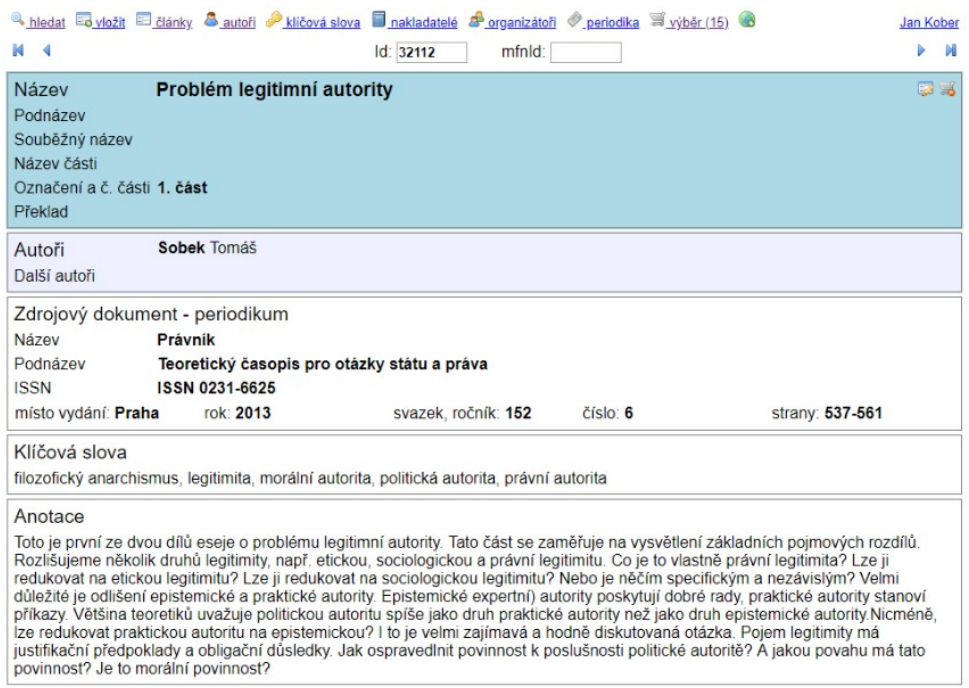

Obr. 8. Ukázka záznamu článku v databázi CLAN s knihovnicky zpracovanou anotací jeho obsahu.

\subsection{PRÁVNICKÁ FAKULTA MASARYKOVY UNIVERZITY - PROJEKT BIBLIOGRAFICKÉHO SOUPISU}

Bibliografie vybraných právnických časopisů a sborníků 1918-1989, provozovaná Právnickou fakultou Masarykovy univerzity, představuje výstup ze stejnojmenného projektu $\mathrm{z}$ roku $2012 .^{28}$ Pro právní historii představuje projekt bezpochyby nemalý prínos, nebot $\mathrm{v}$ tomto rozsahu dosud bibliografie neexistovala, pomineme-li záslužné právněhistorické bibliografie, vydané dříve tiskem. Jako velmi problematickou lze ovšem nahlížet připravovateli databáze $\mathrm{v}$ jejich textu zmíněnou a dnes bohužel rozšířenou neblahou tendenci k umělé, krkolomné a poněkud manipulativní „aktualizaci“ historických textů pro současnost, ${ }^{29}$ jako by právo různých období minulosti snad mohlo být mechanicky a násilně přenášeno do jiného, zcela odlišného historického období. ${ }^{30}$

28 Projekt MUNI/A/0768/2012 „Vytvoření bibliografie právnických časopiseckých článků a sborníkových příspěvků 1918 - 1989. 


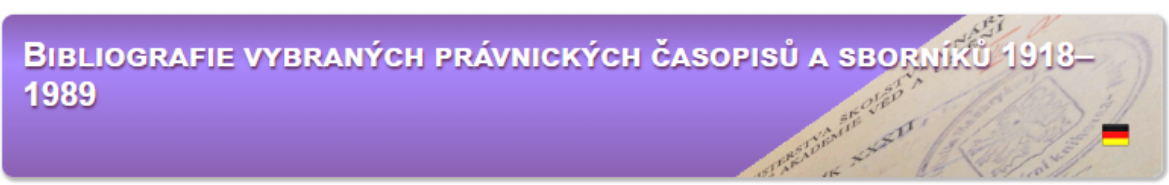

Úvod »O projektu » Bibliografie

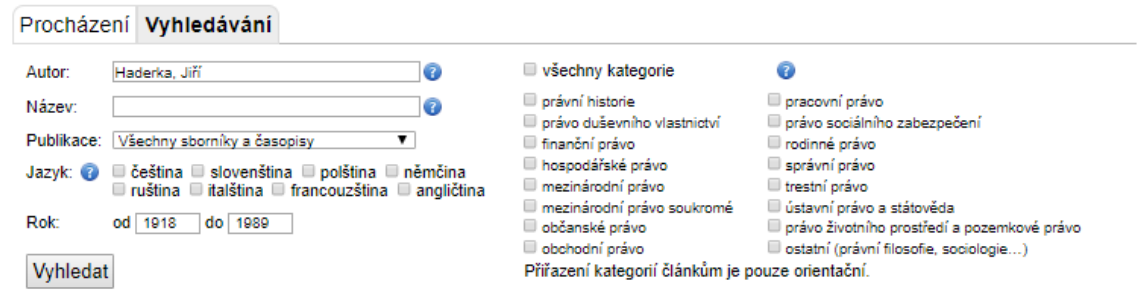

\begin{tabular}{|c|c|c|c|c|c|c|}
\hline \multirow{2}{*}{\multicolumn{7}{|c|}{ Celkem nalezeno článkủ: 129 Zobra: }} \\
\hline & & & & & & \\
\hline \multicolumn{2}{|r|}{ Autor $\mathbf{\Delta} \mathbf{V}$} & Název článku $\mathbf{\Lambda} \mathbf{V}$ & Publikace $\mathbf{\Lambda}$ & Rok $\Delta \mathbf{T}$ & Jazyk & Str. $\mathbf{\Lambda} \mathbf{V}$ \\
\hline 1. & Haderka, Jifï & Moderni genetika a naše současné rodinné právo & Acta Universitatis Carolinae: lunidica & 1973 & cze & 79 \\
\hline 2. & Haderka, Jifíi & $\begin{array}{l}\text { K nẻkterým problémủm konkurence paternitnich } \\
\text { domnének }\end{array}$ & Bulletin advokacie & 1979 & cze & 17 \\
\hline 3. & Haderka, Jifï & $\begin{array}{l}\text { Nẽikeré sporné otázky řizení a rozhodováni o } \\
\text { zpứsobilosti k právnim ứkonúm }\end{array}$ & Bulletin advokacie & 1880 & cze & 13 \\
\hline 4. & Haderka, Jifï & K nékterým paternitnim problémủm & Bulletin advokacie & 1981 & cze & 34 \\
\hline 5. & Haderka, Jifi i & $\begin{array}{l}\text { Význam biologického pưvodu pro platnost určení } \\
\text { otcovstvi dle } \$ \S \S 52,53 \mathrm{ZR}\end{array}$ & Bulletin advokacie & 1881 & cze & 32 \\
\hline 6. & Haderka, Jifïi & Knékterým aspektủm prvni domnẻnky otcovství & Bulletin advokacie & 1882 & cze & 96 \\
\hline 7. & Haderka, Jifï & $\begin{array}{l}\text { K problematice § } 79 \text { obč. zákoniku (zejména z hlediska } \\
\text { promlä́telnosti oprávnéni vêritele) }\end{array}$ & Bulletin advokacie & 1983 & cze & 1 \\
\hline 8. & Haderka, Jifi & K nẻkterým dalšim adoočnim problémủm & Bulletin advokacie & 1883 & cze & 60 \\
\hline
\end{tabular}

Obr. 9. Ukázka vyhledávání v Bibliografii vybraných právnických časopisů a sborníků

${ }^{29}$ Př́íkladem může být z jedné strany „aktualizační“ tendence v přístupu k právní historii např. problematická představa o užitečnosti zařazování určitých segmentů právní historie do výuky občanského práva, nemírné zdůrazňování významu určitých vyučovaných materií římského práva, apod. Tyto „aktualizační tendence lze pozorovat zhruba od doby výročí všeobecného zákoníku občanského (které bylo mohutně připomínáno, přičemž byl tento zákoník často nahlížen nekriticky), a následně od doby přijetí a účinnosti stávajícího občanského zákoníku. (Je však třeba dodat, že zmíněné tendence mohou být $\mathrm{i}$ jen sebezáchovnou snahou o zdůraznění významu historických disciplin $\mathrm{k}$ udržení rozsahu výuky právněhistorických předmětů, potenciálně ohrožovaných kurikulárními reformami). $\mathrm{Z}$ druhé strany lze pozorovat, zvláště v advokacii, jakýsi módní historismus, připisující právu určitých období minulosti bez rozumné příčiny velmi kladné hodnocení, snahy užívat pro dnešní případy stará rozhodnutí meziválečného Nejvyššího soudu, apod.

30 Srov. např. vyjádření PRÁVNICKÁ FAKULTA MASARYKOVY UNIVERZITY. O projektu [online]. [cit. 23.12.2018]. Dostupné https://is.muni.cz/do/law/kat/kdsp/bibliografie/o_projektu.html. 
Vedle kladů má tato databáze i určité nedostatky. Zpracována byla pouze odborná pojednání, nikoli však jiné, kratší útvary - informace o soudních rozhodnutích, kratší komentáře, zprávy, personálie, recenze a jiné podobné typy textů zůstaly stranou, což ovšem hodnotu bibliografie velmi ochuzuje - podobně, jako to kdysi ochuzovalo stejným zpơsobem zpracovanou bibliografii časopisu Právník, připravenou knihovnou Policejní akademie. Na druhé straně je ovšem zřejmé, že podrobnější zpracování by bylo velmi náročné. Drobným nedostatkem, přítomným ovšem pouze u některých do bibliografie zahrnutých časopisů, je absence pozornosti ke zpơsobu stránkování zpracovávané předlohy. Zatímco většina časopisů je číslována průběžně (po skončení roku je ročník knihařem svázán), některé časopisy z nejasných příčin číslovaly pouze v rámci jednotlivých sešitů. Zpracovávatelé bibliografie těchto růzností ovšem nedbali a proto údaj o čísle (sešitu) v bibliografickém údaji u časopisů stránkovaných tímto zpơsobem chybí; čtenář, postupující na základě tohoto neúplného údaje by tak musel prohledat postupně jednotlivá čísla předmětného ročníku. Navzdory výše uvedeným kritickým poznámkám je třeba zdůraznit, že se jedná o projekt velmi pěkný a přínosný.

\section{SNAHA O FORMULACI ODLIŠNÉHO PŘÍSTUPU}

\subsection{CELKOVÉ HODNOCENÍ EXISTUJÍCÍCH PROJEKTŮ}

Jak jsme viděli, dosud tedy vzniklo pouze několik menších, v zásadě izolovaných a nesystematických snah jednotlivých fakultních knihoven digitalizovat si z vlastního fondu některé své vlastní staré knihy. Tyto digitalizace tedy měly většinou paradoxně ráz ochranný (ke vzácné digitalizované knize netřeba pouštět čtenáře, lze je odkázat na digitální obraz) a nikoli, jak by se především nabízelo, ráz doplňovací, tedy pojetí digitalizace coby aktu doplňujícího, zacelujícího mezery, někde i neexistenci či nedostatečnost historického fondu jednotlivých právních knihoven, anebo zacelujícího povodňové ztráty. To bylo dosti zvláštní, nebot se rozhodně nelze domnívat, že by ve velké většině šlo o fondy nějak ohrožené (např. destrukcí papíru) a pomineme-li digitalizaci několika tisků z doby před rokem 1800, usku- 
tečněnou knihovnou PF UK, nešlo ani o fondy kromobyčejně staré a vzácné, pouze z XIX. a XX. století. Zdá se, že se jako motivy vedle ubiquity digitálních faksimilií (jejichž reálná užitečnost je ovšem u úzkoprofilových témat sporná) přistoupily i lenost (míním lenost či neschopnost hledat ve starých knihách ${ }^{31}$ ) a snad i představa, že digitalizovat je moderním trendem, $\mathrm{k}$ němuž je třeba se přidružit. Jmenovitě lze právě ve vztahu k brněnské digitalizaci velmi litovat, že se prvně nezaměřila na knihy před rokem 1800, jejichž dostupnost je často velmi problematická. Naopak např́ílad knihy $\mathrm{z}$ meziválečného období XX. století jsou právním historikům dostupné ve většině velkých knihoven bez obtíží (byt̉ ne $\mathrm{k}$ vypůjčení a byt ne vždy v úplnosti v knihovnách fakultních), a také např́klad knihy ze druhé poloviny XIX. století nebo z období před 1 . světovou válkou nejsou jistě nedostupné ani ohrožené. Nemyslím si však, že je to překvapivé. Tento stav obecně odpovídá určitému nepovědomí o tom, že by cílem každé kvalitní odborné knihovny měl být pokud možno historicky ucelený knižní fond na poli jejího odborného profilu. Zatímco v jiných zemích je taková ucelenost běžnou snahou jednotlivých institucí, projevující se mj. i v aktivní akviziční politice nákupů i historické literatury a také ve snaze získávat v maximální míře knižní dary a pozůstalosti, v českých zemích panuje přístup př́mo opačný, tedy akviziční politika ve vztahu k historickému fondu převážně pasivní. Jedním ze zdrojů tohoto přístupu je i setrvalý a ochromující nedostatek prostoru na přírůstky ve většině knihoven, ostudné podfinancování jejich rozpočtů na nákupy knih (velmi omezující aktivní doplňování fondu nákupy starých knih), a také nedostatek financí na optimální počet odborných sil; kde je personální stav za běžných okolností nedostatečný, těžko lze hledat ochotu např. ke zpracování jednorázových rozsáhlejších přírůstků. ${ }^{32}$ Zčásti šlo o projekty omezené jen na jeden typ dokumentu (digitalizace sbírek zákonů v Praze a v Brně) nebo na úzký okruh nej-

31 Nedostatečné navyknutí studentů na práci s reálnými knihami a časopisy ve fakultní knihovně a schopnost vyhledávat $\mathrm{v}$ nich, jejich zpohodlnění ve světě elektronických právních systémů. Nejlépe by se snad ta schopnost vycvičila, jako i v zahraničí, psaním malých seminárních prací (tř̌eba jen patnáctistránkových), ovšem s důkladnou a průběžnou zpětnou vazbou učitelů. Takové rozsahem malé, avšak náročné práce, tř̌i z různých oblastí práva během studia, by přinesly studentům více, nežli stále se udržující neužitečný relikt magisterské diplomové práce na konci studia. 
cennějších historických dokumentů, často prvotisků (Praha). Rozsáhlejší a úplnější povahu měla pouze nejnovější digitalizace brněnská, snažící se o plošné zpřístupnění historického knihovního fondu vlastní knihovny, avšak její šîře byla poněkud znehodnocena nedostatkem koncepčního výběru digitalizovaných titulů. Samostatně stojí dva bibliografické projekty, každý pokrývající jiné období a lišící se jak v rozsahu zpracovávaných informací (úplné zpracování všech typů textů z časopisů, ne však sborníky vs zpracování pouze odborných pojednání z časopisů, vynechání drobnějších textů, ale zahrnutí sborníků), hloubkou a kvalitou zpracování (komplexní bibliografické záznamy, anotace, podřazování pod autority vs přepsání obsahu ročníků časopisů či sborníků) i zpracovávateli (odborní pracovníci s knihovnickým vzděláním vs studenti). Oba projekty jsou ovšem záslužné svou značnou šîrí.

\subsection{NEDOSTATEK PLNOTEXTOVÉHO ZPŘÍSTUPNĚNÍ}

Především se však jednalo (až na výjimky - parlamentní knihovny, Krameria a brněnské fakultní knihovny ${ }^{33}$ ) o digitalizace bez provedení OCR. Takové pojetí je však problematické, nebot neumožňuje plnohodnotnou práci s digitálním textem, zvláště pak jeho prohledávání. Toto pojetí jsme se proto rozhodli pro náš projekt Národní právní dědictví opustit a navzdory vědomí mimořádné náročnosti odlišné cesty jsme se rozhodli náš projekt utvářet jako plnotextový, tedy nejen zpřístupňující naskenované předlohy, ale zároveň z nich i vytvářenící pomocí nástrojů OCR plné texty a tyto texty navíc podrobující korekturám.

${ }^{32}$ Mohu uvést př́iklad, který jsem sám viděl: nejmenovaná univerzitní knihovna s knižním fondem teprve dobudovávaným a ani zdaleka ne úplným vyjadřovala namísto rozumně očekávatelné radosti z hodnotné akvizice přímo hrůzu a odmítání, když se po ní žádalo, aby darem převzala do svého fondu a pozvolna zpracovala nikterak velké množství knih (pouhých asi osm tisíc svazků) hodnotné staré odborné literatury z oblasti společenských věd, vesměs zahraniční a ve fondu knihovny nezastoupené. Knižní celek pro odpor vedení knihovny převzat nebyl a musel být rozdán studentům.

${ }^{33}$ Zatímco texty v repozitáři parlamentní knihovny zřejmě prošly korekturou, takže jsou bez podstatnějších chyb, texty $\mathrm{v}$ Krameriu korigovány nebyly, což u nekvalitně tištěných předloh (např. denní tisk s nízkou kvalitou papíru i literek) nutně vede k nekvalitnímu plnému textu. 


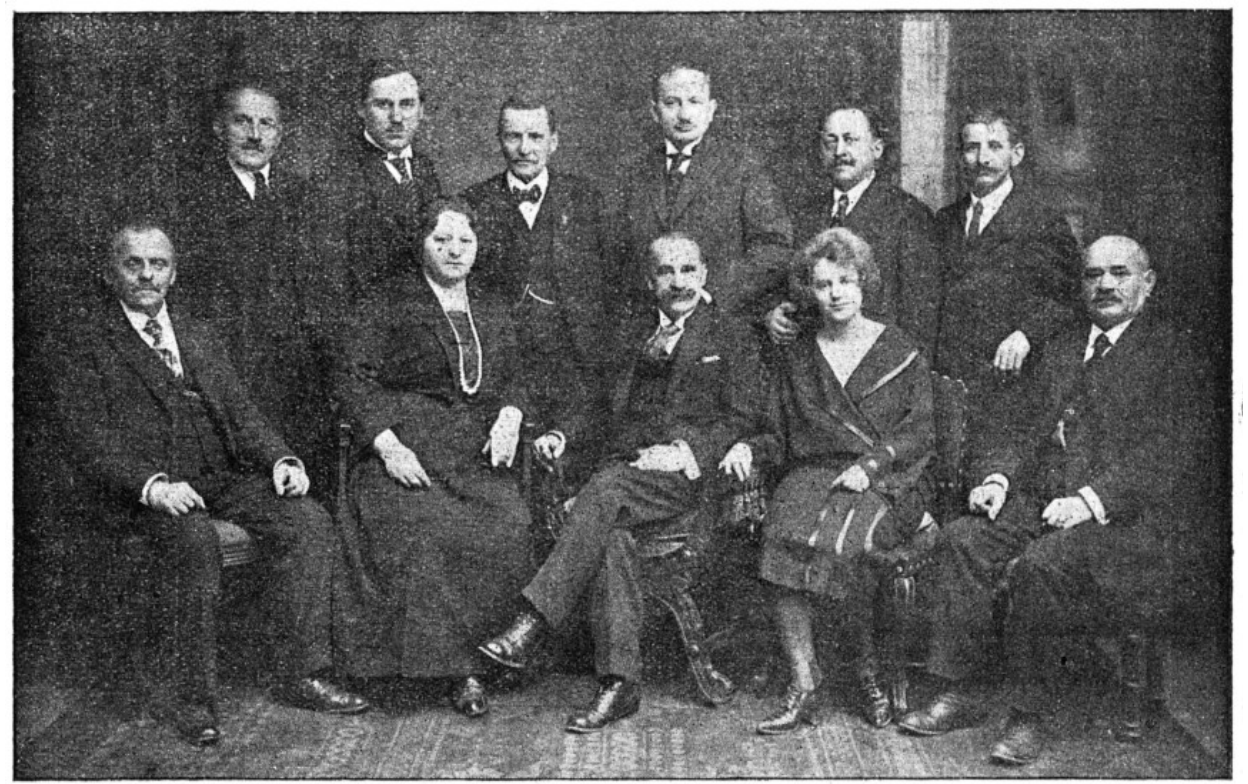

Obr. 10. Historické vyobrazení členů a členek lichevních soudů z roku 1922, otištěné $\mathrm{v}$ jednom $\mathrm{z}$ periodik, digitalizovaných $\mathrm{v}$ projektu Národní právní dědictví.

\subsection{NEDOSTATKY V METADATECH A VE VYHLEDÁVÁNÍ}

Společné mají posavadní projekty i spíše skromnou tvorbu metadat (někde metadata i chybí), popřípadě se nevzdatují $\mathrm{k}$ nejnižším dělitelným celkům (např. článek, předpis, rozhodnutí), ale jen $\mathrm{k}$ dokumentu jako celku (knižní svazek). Také vyhledávací nástroje existujících projektů zpravidla nebyly př́liš zdařilé (s výjimkou brněnského bibliografického projektu). Bez vytvoření kvalitních metadat nebo s metadaty nepř́liš úplnými však není kvalitní historický právní informační systém myslitelný a bez kvalitních vyhledávacích nástrojů jsou zase metadata pouze zčásti využitelná. Rozhodli jsme se proto $\mathrm{v}$ našem projektu položit na tyto dva okruhy hlavní důraz: opatřit nejmenší dělitelné jednotky (články, rozhodnutí, atd.) vlastními metadaty a zároveň vyvinout takové vyhledávací nástroje, které by umožnily vysoce náročnou práci s plným textem i metadaty. 


\subsection{ZVOLENÉ INSTITUCIONÁLNÍ ŘEŠENÍ}

Bylo možné se domnívat, že náhlá rána povodňových ztrát na straně jedné a dlouhodobý nedostatek historického právního knižního a časopiseckého fondu na straně druhé by mohly vést $\mathrm{k}$ solidaritě a ke vzájemně výhodné kooperaci mezi fakultami v oblasti digitaliace. Autor těchto řádek se před více než osmi lety pokusil veřejně vyzvat $\mathrm{k}$ založení digitalizačního spolku (sdružení) všech čtyř českých fakult, ${ }^{34}$ avšak bez ohlasu. Př́čcinou toho byl asi obecnější problém vzájemné izolace čtyř českých fakult, žijící myšlenkově i personálně (fakultní autarkie, inzucht) ve svých uzavřených světech a druhé fakulty - jakkoli nežádoucí takový stav je - vnímající spíše optikou „konkurence“ a „boje o zdroje“ nežli solidarity a kooperace. Ukázalo se, že vhodnější a účinnější cestou bude zpřístupnění historických textů činností centrální výzkumné instituce - Ústavu státu a práva Akademie věd. Jedná se o postup, který se osvědčil např́klad v Německu, kde právě centrální výzkumné instituce učinily v kvalitním zpřístupnění historické právní literatury velmi mnoho. Knihovna Ústavu státu a práva AV ČR má - podobně jako knihovny obdobných pracovišť v zahraničí - náročnou a zodpovědnou úlohu neformální ústřední odborné právní knihovny v naší republice. Disponuje kvalitní a na zdejší poměry ještě relativně ucelenou sbírkou historického fondu zdejší právní literatury, ucelenější než sbírky většiny fakultních knihoven. To znamená možnost digitalizovat velkou část textů přímo z vlastních knižních fondů; zároveň se však nevyhýbá výpůjčkám předloh $\mathrm{k}$ digitalizaci z jiných institucí. Ústav je institucí, která není, jako by byla fakulta, do jisté míry vázána např. sledováním zájmů své vlastní univerzity. Vodítkem pro práci projektu Národní právní dědictví je naopak prospěch celonárodní, tedy prospěch nikoli pouze odborných pracovníků Ústavu státu a práva, ale i odborných pracovníků všude jinde $\mathrm{v}$ republice, na všech univerzitách i mimo ně, a potažmo pak prospěch všech občanů či jiných osob v zahraničí o určitý historický právní text se zajímajících, jinak řečeno: veřejný zájem. ${ }^{35}$

${ }^{34}$ KOBER, J. Mezi Clio a Justitií: psaní o starší právní vědě a návrat jedné antologie. Právník. Praha: Ústav státu a práva AV ČR. 149 (2010), č. 4, s. 419, 429-430. ISSN 0231-6625. 


\section{OBSAH DATABÁZE NÁRODNÍ PRÁVNÍ DĚDICTVÍ COBY PŘÍKLADU PRÁVNĚHISTORICKÉHO INFORMAČNÍHO SYSTÉMU}

\subsection{VŠEOBECNĚ O AKTUÁLNÍCH OBSAHOVÝCH SLOŽKÁCH (MODULECH)}

Chceme-li přiblížit obsah databáze v jejím aktuálním - dosud pracovním stupni vývoje, je třeba předně zmínit časopisecké články, dále pak jiné texty v neperiodických publikacích (pocty a jiné sborníky, encyklopedie), monografie a konečně informace o soudních rozhodnutích. Volně se pak přimyká obsahová složka bibliografická, určitým způsobem zpř́stupňující údaje o obsahu výše uvedených složek.

\subsection{OBSAHOVÁ SLOŽKA ČASOPISECKÝCH ČLÁNKŮ}

Základem pro utváření obsahu databáze byly a jsou pro nás $\mathrm{v}$ počátečním stádiu články v odborných časopisech (z časopisů jako zdrojové jednotky ovšem získáváme zčásti také obsahy jiných modulů, např. informace o soudních rozhodnutích). Rozsahem tvoří vedle soudních rozhodnutí v současnosti nejdůležitější část databáze. Při výběru časopisů se soustřed’ujeme přednostně na časopisy jednak vědecky významné, ${ }^{36}$ jednak na časopisy hưře dostupné, $\mathrm{z}$ jazykového hlediska byla prozatím upřednostněna čeština. ${ }^{37} \mathrm{O}$ pořadí je rozhodováno na základě hodnocení tvůrci projektu. Dlouhodobým cílem je, aby databáze Národní právní dědictví obsáhla veškeré odborné právní časopisy, vycházející na území Československa v jakémkoli jazyce, včetně časopisů vycházejících pouze efemerně, časopisů na

35 Text oddílu vychází z úvah, vyslovených již v KOBER, J.; MATEJKA, J. Právněhistorická databáze Národní právní dědictví. In: SUCHOŽA, J.; HUSÁR, J.; HUČKOVÁ, R. (ed.). Právo, obchod, ekonomika VII. Košice: Univerzita Pavla Jozefa Šafárika, Právnická fakulta, 2017, s. 225 ff. ISBN 978-80-8152-528-5.

36 Míněny jsou z období, na které se projekt soustřed’uje, především Právník, Sborník věd právních a státních, brněnské Časopis pro právní vědu, Vědecká ročenka a bratislavský Právny obzor, coby časopisy s vědeckou ambicí, oproti časopisům orientovaným spíše prakticky či jako tribuna určité profesní skupiny.

37 V první etapě upřednostňujeme časopisy jazykově české a slovenské, dále samozřejmě budou doplněny i čs. časopisy německé a mad’arské. 
pomezí právní a státní vědy a věd jiných, popřípadě interních bulletinů, apod.

\title{
Posudek o návrhu zákona o účasti zaměstnancư na správě a čistém zisku podniků. \\ K posudku tomuto vyzvána byla pražskou obchodni komorou Právnická Jednota v Praze; posudek pochází z péra univ. prof. Dr. V. Mildschuha.
}

\section{(Tisk 1701 Národního shromáždění r. 1919.)}

\begin{abstract}
Zákonem navrženým členy Národniho shromážděni
Tučným, Laubem a spol, má býti zahájena t. zv. socialisace, t. j. ona opatření, jimiž má se dělnictvu dostati účasti na podnikáni, aniž nebo dříve než by výroba byla kolektivně uspořádána. To se má dle návrhu (zákona právě zminẽného stát

jednak tím, že se dělnictvu dostane účasti na správe, jednak tím, že se mu má dostati též účasti na čistém zisku podniku.

1. Účast na správĕ. Té má býti docileno tím, že o všech dủležitých opatřeních správy podniku se týkajicích, jmenovitě též o prìijimání a propouštěni dělnikủ a úredníkủ, jejich pensionování, o rozdělení práce, o kázni, o dủtkách a pokutách, o rozšîrení závodủ a o změnách ve výrobě, o rozdělení čistého zisku atd. nemá rozhodovati již majitel sám, nýbrž toliko spolu se závodním výborem, resp. předsednictvem dělnickým a úrednickým (viz § 16.). Při tom má dle § 21. majitel nebo správa podniku míti tolik hlasủ, kolikrát 200000 frankủ čitá závodní kapitál, závodni výbor, resp. předsednictvo pak tolik hlasủ, kolik dvacitek zamèstnancủ má závod.

Ustanoveni ta neznamenaji vlastně nic jiného než združstevnění podnikủ, arci s tím rozdilem, že pr̆i výrobním družstvu rozhodujî o správě podniku toliko dělníci v družstvu zaměstnaní, kdežto $v$ podnicích dle hơ̌ejších ustanovení socialisovaných má vedle dëlníkủ a úư̌ednikủ rozhodovati též majitel závodu. Leč vliv majitele bude tu jen velmi malý. Vždyt $v$ mnohých prípadech závodnimu výboru bude přislušet vice hlasủ, než jemu, i bude tu odsunut zcela stranou. Ale i tam, kde tomu
\end{abstract}

Obr. 11. Příklad plného textu článku: Mildschuhův Posudek návrhu zákona o účasti zaměstnanců na správě a čistém zisku podniků z Právníka 59 (1920).

\subsection{OBSAHOVÁ SLOŽKA MONOGRAFIÍ}

Další obsahovou složkou jsou monografické spisy. I zde je dlouhodobým cílem projektu obsáhnout vše podstatné, co v tomto formátu na území Československa vzniklo, bez ohledu na jazyk, nakladatele (tedy i drobné spisy vydané vlastním nákladem autora) a na otázky přetisku (zahrnutí separátů, pokud vyšly s vlastní odlišnou paginací). V počátečním výběru jsou upřednostněny monografie špatně dostupné (např. vydané pouze $v$ malém nákladu) ${ }^{38}$ a jazykově české, $\mathrm{v}$ první skupině zvláště $\mathrm{z}$ meziválečného období, a přihlíženo je též $\mathrm{k}$ obecné vědecké hodnotě jednotlivých děl. Přihlíží se též $\mathrm{k}$ tomu, které monografie vyšly nedávno $\mathrm{v}$ reprintech a jsou tedy pohodlně dostupné - tyto budou zařazeny až v poslední fázi. O pořadí je rozhodováno na základě hodnocení tvůrci projektu, přičemž jsou zohledňovány i technické otázky a zastoupení různých typů dokumentů v databázi.

\footnotetext{
38 Nejsou tedy primárně (zpravidla) zařazovány meziválečné učebnice, dodnes solidně dos-
} tupné a některé $\mathrm{z}$ nich i v současnosti reprintované. $\mathrm{V}$ budoucnu je však rovněž zahrneme. 


\subsection{OBSAHOVÁ SLOŽKA TEXTU゚ VE SBORNÍCÍCH A ENCYKLOPEDIÍCH}

Do samostatné obsahové složky jsme vyčlenili texty ve sbornících a odborných právních encyklopediích. Cílem projektu je postupem času zahrnout veškeré československé pocty a jiné sborníky. Z právních encyklopedií je např. součástí databáze Všeobecný slovník právní a bude jí také Slovník veřejného práva československého.

\section{Cizoložství}

\footnotetext{
I. Pojem. Cizoložství záleží v tom, že dvě osoby, z nichž aspoň jedna jest v platném svazku manželském, souloži spolu s vědomím, že tím porušuji platné manželství. l osoba neoddaná dopoušti se cizoložstvi, ví-li o manželstvi osoby, s niž soulouží. Cizoložství před pokládá platné manželství ; poněvadž pak rozvod od stolu a lože nezbavuje manžely povinnosti věrnosti manželské, jest is takovými manželi cizoložství možno.

II. Právo soukromé. Cizoložství jest dle $\$ 67$ a 94 o. o. z. překážkou manželství, již dbáti jest z povinnosti úrední a jež má za následek neplatnost manželstvi osob, jež spolu cizoložství se dopustily. Cizoložství musí však prokázáno býti dřive, než se manželství uzavře a sice bud' před soudem civilním, ưradem trestním, nebo před

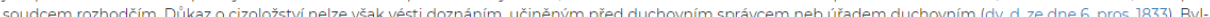
li jeden z manželủ uznán vinným cizoložstvim, múže ku žalobě manžela druhého dle $\$ 109$ ०. 0. z. nalezeno býti na rozvod od stolu a lože a u křestanủ nekatolikủ dle $\$ 175$ o. o. z. i na rozloučení
}

Obr. 12. Ukázka hesla z Všeobecného slovníku právního od F. X. Veselého z roku 1896.

\subsection{OBSAHOVÁ SLOŽKA INFORMACÍ O SOUDNÍCH ROZHODNUTÍCH}

Velmi zajímavým modulem je obsahová složka informací o soudních rozhodnutích. Tato zahrnuje jednak soudní rozhodnutí, vydávaná v hlavních sbírkách (Bohuslav, Vážný), jednak i rozsáhlou a nepatrně známou masu informací, vydávanou časopisecky, zvláště pak v časopise Právník, ale i jinde a před rokem 1918 nahrazujících podstatnou měrou české sbírky. Informace o soudních rozhodnutích mají velmi různorodou povahu, od relativně ustálených podání meziválečných sbírek až po kritické přehledy a komentáře rozhodování v určité otázce.

\subsection{OBSAHOVÁ SLOŽKA OSOBNÍCH BIBLIOGRAFIÍ}

Zvláštním doplňkovým modulem je složka osobních bibliografií. Tento modul naváže na zkušenosti projektu CLAN a umožní ve zvláštním modulu autoritní procházení bibliografií jednotlivých osob. $\mathrm{V}$ budoucnu by měly být vybrané bibliografie důležitých vědců knihovnicky doplněny $\mathrm{z}$ dalších zdrojů tak, aby byly, alespoň pokud se týče odborné literární činnosti, 
úplné a mohly tak představovat pod označením Akademická bibliografie autoritativní zdroj.

\section{ZPŮSOBY VYUŽÍVÁNÍ DATABÁZE NÁRODNí PRÁVNÍ DĚDICTVÍ}

\subsection{DVA DRUHY OBJEKTU゚: TEXT A FAKSIMILE}

Obsah je v databázi Národní právní dědictví zpřístupňován jednak v podobě plnotextové, vzniklé převodem naskenovaných předloh pomocí nástrojů OCR, následně lidskými opravami korigovaného. Je však také všude zároveň zpř́istupněn i $\mathrm{v}$ podobě faksimile, tedy $\mathrm{v}$ podobě naskenovaných historických předloh. Řada čtenářů z dobrých příčin upřednostňuje faksimili, nebot přináší výhody práce $s$ textem $v$ jeho původní grafické podobě.

\subsection{PROCHÁZENÍ STRUKTUROU DOKUMENTŮ}

Stejně jako všechny kvalitní databáze, umožní Národní právní dědictví pohyb uživatele procházením strukturou dokumentů (browsing, prohlížení). Tento zpơsob používání je zvláště příhodný pro uživatele bez specifického hledaného cíle, se zájmem o určitý dokument, typ dokumentů nebo historické období jako celek.

\subsection{EXPORT INFORMACÍ}

Mimořádně důležitým a nezbytným prvkem každého informačního systému je široká možnost exportu informací. Tento můžeme třídit na export úplných celků $\mathrm{k}$ dalšímu použití offline, a export kopírováním textu přímo z prohlížeče. Národní právní dědictví umožní stahování naskenovaných předloh na všech přirozených úrovních textových celků, tedy jednak na úrovni každého dokumentu jako celku (stažení celého ročníku časopisu, celého ročníku sbírky rozhodnutí, celého svazku monografie či sborníku), jednak na úrovni středních textových jednotek (čísla časopisu), jednak na úrovni nejnižších samostatných textových jednotek (jednotlivých článků, jednotlivých soudních rozhodnutí, encyklopedických hesel, statí v poctě či $\mathrm{v}$ jiném sborníku). Ve vztahu $\mathrm{k}$ převedenému textu bude umožněno 
stahování textů pouze na úrovni nejnižších textových jednotek, tedy jednotlivých článků, soudních rozhodnutí, encyklopedických hesel apod. Nejnižší úroveň textových jednotek bude generována na základě požadavku uživatele; naopak rozsáhlé textové jednotky (celé dokumenty) budou v PDF vygenerovány předem a připraveny ke stažení, aby jejich generování zbytečně nezatěžovalo systém. $\mathrm{V}$ kopírování textů přímo z prohlížeče nebudou kladena omezení, tj. nebude třeba generovat export souboru, ale bude možné kopírovat do schránky v rozsahu aktuálně otevřené textové jednotky (např. celé soudní rozhodnutí).

\subsection{VYHLEDÁVÁNÍ V DATABÁZI NÁRODNÍ PRÁVNÍ DĚDICTVÍ}

\subsubsection{VŠEOBECNÁ CHARAKTERISTIKA VYHLEDÁVÁNÍ}

Vyhledávání je rozčleněno do dvou základních modů: jednoduchého a podrobného. Jednoduché vyhledávání má sloužit libovolnému uživateli, zadávajícímu nekomplikovaný dotaz. Toto vyhledávání je nastaveno jako výchozí (defaultní). Naopak podrobné vyhledávání je míněno jako vyhledávání určené pro složitější dotazy s možností nejrůznějších způsobů limitace, kombinace a zužování výběru. Sloužit by mělo především vědcům a dostupné bude prokliknutím z modu vyhledávání jednoduchého, resp. i trvalým uživatelským nastavením coby vyhledávání výchozí. V následujícím textu přibližujeme pouze vyhledávání v jednoduché verzi (základní vyhledávání). Popis podrobného vyhledávání, průběžně vyvíjeného, by v tomto článku žádal př́liš mnoho místa a bude popsán samostatně v budoucnu.

\subsubsection{MASKA JEDNODUCHÉHO VYHLEDÁVÁNÍ}

Jednoduché vyhledávání je uskutečňováno z přehledné vyhledávací masky, tvořené řádky $\mathrm{k}$ zadání dotazu a dále několika základními nastaveními. Dotaz lze zadávat jednak $\mathrm{k}$ vyhledání $\mathrm{v}$ plných textech, jednak $\mathrm{v}$ názvech dokumentů, podle klíčových slov či podle autora. Výhodou takto samostatně umístěných hlavních vyhledávacích ráádků je eliminace ztráty času, která by nastala např. při výběru zúžení vyhledávání z rolety nebo jinak. Uživatel tak může zadávat základní, nejčastější typy dotazů bez dalšího klikání. 
Upozornění: Aplikace je v současnosti ve zkušebni fázi (verze alfa). Některá nastavení a odkazy nejsou zatím funkční a data jsou dosud pouze v pracovni verzi!

Vyhledávání v plném textu dokumentů:

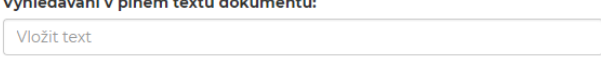

- Casopisy Právni encyklopedie

- Soudní rozhodnutí

Pocty a sborniky

Vyhledávání v názvu dokumentu:

Historický filtr:

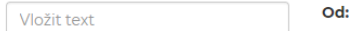

Vyhledávání dle klíčových slov:

Do:

- Vẽdecké monografie

Vložit text

- Historické předpisy

Vyhledávání dle autora:

Vložit text

Odeslat Storno

Obr. 13. Celkový náhled na základní (jednoduchou) podobu vyhledávací masky databáze Národního právního dědictví.

Dalším zúžením, které lze v jednoduchém vyhledávání využít, je zúžení podle druhu dokumentu. Uskutečňuje se pomocí zatržítek v kategoriích Časopisy, Soudní rozhodnutí, Vědecké monografie, Historické předpisy, Právní encyklopedie a Pocty a sborníky. Výchozím nastavením je zatržení všech těchto kategorií. Odstraňováním zatržení lze tedy výběr zužovat. Konečně je v jednoduchém vyhledávání možné užít rovněž jednoduchý historický filtr, v němž lze zadat data, mezi nimiž chce uživatel vyhledávat.

\subsubsection{VÝPIS VÝSLEDKŮ}

Po zadání plnotextového vyhledávacího dotazu získá uživatel výpis výsledků, z něhož následně může dále pokračovat na plné texty jednotlivých výsledků. Vyhledáme-li například slovo „rozluka“ a nenastavíme-li žádné filtrování, bude výpis vypadat následujícím způsobem: 


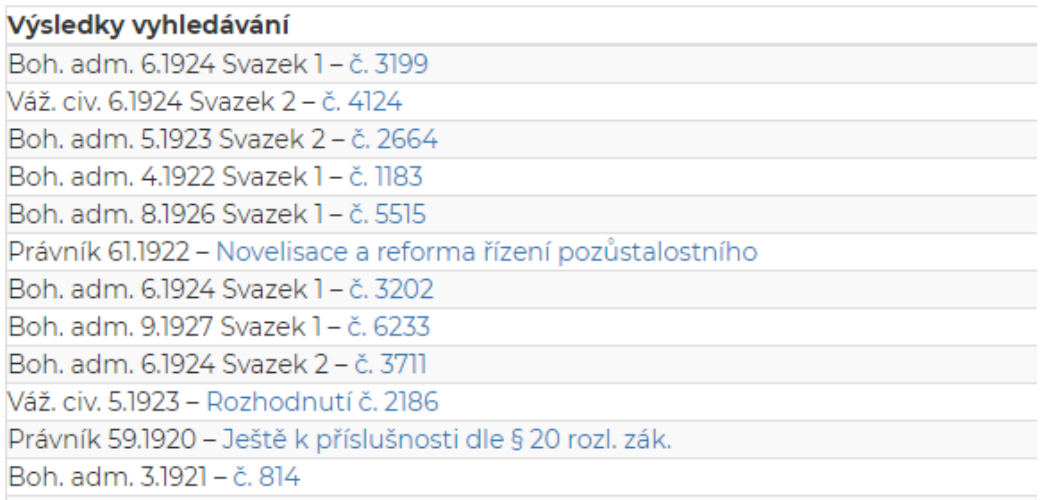

Obr. 14. Výpis výsledků vyhledávání v databázi Národního právního dědictví.

Jak je vidět na obrázku, jsou nalezené výsledky označeny jednak základními údaji o dokumentu, např. Boh. adm. 4.1922 (Bohuslavova sbírka nálezů ve věcech administrativních, ročník čtvrtý za rok 1922). Kde je dokument rozdělen do více svazků (např. u sbírek), je uvedeno i číslo svazku; konečně je pak uveden i název textu (např. u rozhodnutí č. 1183).

V budoucnu předpokládáme rovněž doplnění výpisu výsledků s náhledy nalezeného slova $\mathrm{v}$ jeho usazení, tedy $\mathrm{s}$ náhledem výseku několika vět $\mathrm{z}$ předmětného výsledku, $\mathrm{v}$ němž je slovo nalezeno, aby uživatel mohl hned na výpisu výsledků uvážit kontext, v němž se hledané slovo nachází a usoudit, zda má smysl přejít na plný text toho kterého výsledku.

\subsubsection{ZOBRAZENÍ PLNÉHO TEXTU VÝSLEDKU}

Z výpisu výsledků se lze prokliknout na plný text výsledku, např. na text historického článku nebo soudního rozhodnutí. Tento plný text je výsledkem převodu historických předloh pomocí nástrojů OCR a náročné korektury, odstraňujících chyby a vytvářející jednak metadata každého textu, jednak provazby $\mathrm{v}$ podobě vzájemných odkazi̊. $\mathrm{Z}$ jednoho textu tak bude možné prokliknutí na jiný článek či soudní rozhodnutí, které je $\mathrm{v}$ předmětném textu zmiňováno či citováno.

Ze zobrazení bude možné vždy přejít též do zobrazení faksimile (skenů) historické předlohy. $\mathrm{V}$ budoucnu by mělo být rovněž propojením faksimile a plného textu umožněno plnotextové prohledávání pod samotnou faksimi- 
lí. Nedílnou součástí zobrazení výsledku bude také jeho export (k tomu níže v samostatném oddílu).

Uznáno-li právoplatně na rozluku manželství z viny obou manželu, Ize se domáhati zrušení smluv svatebních. Smlouva, jíž snoubenec snoubenku za peněžitý přínos bere do spoluvlastnictví nemovitosti, jest smlouvou svatební. Zruší-li se tato smlouva pro rozluku manželství, zjedná se ohledně vlastnictví dřívější stav knihovní; otázku, zda vymažou se dluhy, jimiž manželka zatižila svou polovici nemovitosti, dlužno rešiti od prĭipadu k připadu.

(Rozh. ze dne 23. ledna 1923, Rv 1 704 22.).

$\checkmark$ roce 1910 uzavrel žalobce se žalovanou snaatek a postoupil jí notářským spisem ze dne i 8 . listopadu 1910 polovinu své usedlosti proti prínosu $5800 \mathrm{~K}$ a jedné krávy v ceně 200 K. Dne 20. července 1919 podala žalovaná na žalobce žalobu o rozluku manželství, již bylo právoplatné vyhověno a manželství rozloučeno $z$ viny obou stran. Dne 8. ledna 1920 žaloval manžel manželku na rozvod z jeji viny, z kteréžto žaloby sešlo vzhledem k rozhodnutí o rozluce. Na základĕ rozluky manželství domáhal se manžel zrušeni svatebni smlouvy. Procesní soud prvé stolice žalobě vyhověl, a uznal žalovanou manželku povinnou, vrátiti žalobci polovinu usedlosti, obtiženou dle stavu v době podáni žaloby (12. dubna 1920) proti tomu, že ji žalobce zaplati 5800 K a vydá jednu krávu, zamítl však nárok žalobcưv by žalovaná byla uznána povinnou dáti svým nákladem vymazati dluhy a závady vrácenou polovici usedlosti postihnuvši až do dne 12. dubna 1920. Odvolací soud k odvoláni obou stran rozsudek potvrdil a uvedl k žalobcovu odvoláni v dưvodech: Právem uznal procesní soud prvé stolice na zrušeni smluv notár̆ským spisem uzavrených, ježto

Obr. 15. Příklad plného textu soudního rozhodnutí: Váž. civ. 5.1923 -

Rozhodnutí č. 2196

\subsection{OSOBNÍ PRACOVNÍ PROSTŘEDÍ}

Národní právní dědictví v budoucnu rovněž nabídne možnost přihlášení a používání osobního pracovního prostředí s trvalými nastaveními, možností ukládání, poznámek, návratu ke starým, dříve zadaným dotazům, vytvářením vlastních tematických sbírek dokumentů (shromážděných např. za účelem studia určitého konkrétního problému), atd.

\subsection{AUTORSKÁ PRÁVA MAJETKOVÁ}

Z pohledu autorskoprávního je projekt orientován výlučně na díla, u nichž uběhla doba trvání majetkových práv (tj. zpravidla více než 70 let po smrti autora) ve smyslu ustanovení § 27 zákona č. 121/2000 Sb., o právu autorském, o právech souvisejících s právem autorským a o změně některých zákonů (autorský zákon), ve znění pozdějších předpisů; projekt tak nepočítá s uzavíráním specifických dohod s vykonavateli těchto práv ze strany jejich současných dědiců.

Výsledky projektu, včetně programu, budou přístupné veřejnosti dle zásad open access a nekomerčního volného šíření výsledků (open source platforma - viz níže). Hlavní výsledek projektu, jakož i všechny navazující 
výsledky, jsou vytvářeny řešitelským týmem $\mathrm{v}$ režimu zaměstnaneckých děl dle § 58 zákona č. 121/2000 Sb., o právu autorském, o právech souvisejících s právem autorským a o změně některých zákonů (autorský zákon), ve znění pozdějších předpisů, tj. jako součást plnění práv a povinností vyplývající z pracovněprávních vztahů. Právní povaha takto zvoleného režimu nabízí co do rozsahu práv zaměstnavatele zcela jedinečné postavení při následném výkonu majetkových práv $\mathrm{k}$ těmto dílům, a to včetně širokých možností úprav a jeho dalšího neomezeného (nekomerčního) šíření. Po skončení projektu bude docházet $\mathrm{k}$ jeho aktualizaci $\mathrm{v}$ reálných kontextech. ${ }^{39}$

\subsection{ZVLÁŠTNÍ REŽIM ZÁKONA O SVOBODNÉM PŘÍSTUPU K INFORMACÍM}

Z pohledu samotného účelu projektu, spočívajícího primárně ve zveřejňování historických právních písemností ze strany veřejné výzkumné instituce, je nutno pamatovat i na specifický zákonný režim svobodného přístupu k informacím, zejména pak ustanovení § 4b zákona č. 106/1999 Sb., o svobodném přístupu $\mathrm{k}$ informacím, ve znění pozdějších předpisů, podle kterého je třeba veškeré informace poskytovat zveřejněním poskytovatelem všech formátech a jazycích, ve kterých byla vytvořena, přičemž alespoň jeden z těchto formátů musí být otevřený a, je-li to možné, též strojově čitelný (je-li to možné a vhodné, zveřejní povinný subjekt spolu s informací též metadata, která se k ní vztahují. Formát i metadata by měly co nejvíce splňovat otevřené formální normy). Uvedený požadavek zákona je důsledkem reakce na změny $\mathrm{v}$ evropské legislativě, konkrétně na přijetí směrnice č. $37 / 2013$, kterou byla novelizována směrnice č. 2013/98, a to za účelem zajištění př́istupu veřejnosti $\mathrm{k}$ tzv. otevřeným datům jako specifickému obsahu, který s ohledem na formu i zveřejnění neomezuje žádné uživatele ve způsobu jejich použití a opravňuje všechny uživatele $\mathrm{k}$ jejich dalšímu šíření, pokud při tomto využití a šíření bude uveden autor dat

\footnotetext{
39 K tomu více viz např. KORBEL, F.; MELZER, F. Společenské a právní základy zveřejňování judikatury a způsoby jeho realizace. Právní rozhledy, Praha: C. H. Beck, 2011, č. 9; s. 314321. ISSN 1210-6410; MYŠKA, M.; Vybrané právní aspekty otevřeného přístupu k vědeckým informacím. Právní rozhledy, 2014, č. 18, s. 611-619. ISSN 1210-6410.
} 
a pokud i ostatní uživatelé budou mít stejná oprávnění s dále šířenými daty nakládat.

\section{TECHNOLOGICKÁ IMPLEMENTACE}

\subsection{PODSTATNÉ PRINCIPY ZVOLENÉHO TECHNOLOGICKÉHO ŘEŠENÍ}

\subsubsection{HLAVNÍ VÝCHODISKA}

Databáze Národní právní dědictví byla navržena jako typická webová aplikace. Cílem bylo řešení otevřené, stabilní, spolehlivé, bezpečné a také řešení do budoucna rozšiřitelné. Zvolené řešení by mělo zaručit, že i po letech bude aplikaci možno jednoduše udržovat a rozvíjet.

\subsubsection{POŽADAVEK OTEVŘENOSTI}

Projekt klade důraz na používání knihoven a dalšího software, který je otevřený (open source, svobodný software, viz dále). Uvedené knihovny a software dovolují rozvíjet projekt libovolným způsobem bez jakéhokoliv omezování, které obvykle přináší uzavřený software a jeho pravidla použití. Veškeré námi použité komponenty neomezují ani uživatele, ani vývoj.

\subsubsection{POŽADAVEK STABILITY}

Pokládáme za podstatné užít technologie, které se $\mathrm{v}$ čase př́liš nemění. Mnoho $\mathrm{z}$ moderních technologií se prudce vyvíjí (často javascriptové knihovny, např. Angular). Tyto technologie dochází postupem let značných přepracování a projekty na nich závislé, musí být opakovaně přepracovávány, často i velmi zásadním způsobem. Technologie užité v projektu Národní právní dědictví jsou dlouhodobě zavedené. Pravděpodobnost, že bude dostatek vývojářů schopných pracovat $\mathrm{v}$ nich i po mnoha letech, je tedy nemalá.

\subsubsection{POŽADAVEK SPOLEHLIVOSTI}

Pro projekt jsme upřednostnili užití již zavedeného softwaru. To umožňuje stavět na již odladěném řešení a umenšuje nutnost věnovat značný čas ladění užitých knihoven. 


\subsubsection{POŽADAVEK BEZPEČNOSTI}

Zvolili jsme technologie, které jsou napadány jen zř́íka a jejich spolehlivost je velmi vysoká. Potenciálně slabší prvky (aplikační server, databáze) jsou chráněny a nejsou zvenku přímo dostupné.

\subsubsection{POŽADAVEK ROZŠIŘITELNOSTI}

Vedle možnosti projekt stále vylepšovat mohou růst požadavky na další funkce a výkonnostní parametry. Těmto požadavkům vyhovují námi vybraná již etablovaná open source řešení.

\subsection{OTEVŘENÁ SOFTWAROVÁ ŘEŠENÍ (OPEN SOURCE LICENCE)}

\subsubsection{VŠEOBECNÉ OTÁZKY}

$S$ technologickou rovinou, resp. přesněji technologicko-aplikační problematikou, je nedílně spojena i určitá reflexe existující otevřených softwarových řešení (typicky open source licencí), jejichž uvážlivý výběr může mít zásadní dopad nejenom na financovatelnost, resp. nákladovost projektů tohoto typu, ale i na jejich dlouhodobou udržitelnost v čase, a to jak ve smyslu materiálně-technologickém, tak i právním, zejména pak licenčním (viz níže) či soutěžním; ${ }^{40}$ racionální a především odpovědná volba vhodné open source licence či jiné obdobně otevřené platformy umožňuje použít, modifikovat, či jinak využívat zdrojové kódy či jiné součásti třetích stran, zároveň je umožněno tyto součásti přezkoumávat a upravovat pro vlastní potřebu, a to zpravidla zdarma a za dodržení minimálních povinností, ${ }^{41}$ tj. bez dalších licenčních či jiných poplatků.

\footnotetext{
${ }^{40}$ Např. i z rozhodovací praxe českého Úřadu pro ochranu hospodářské soutěže vyplývá, že „(d)odavatelem předložený informační systém by neměl být postaven na platformě jediné softwarové společnosti nerespektující technologickou neutralitu - otevřenost pro všechny dodavatele s tím, že by měl spočívat $\mathrm{v}$ tzv. otevřeném formátu, který nemá právní omezení na jeho používání. Primárním cílem je zde garance dlouhodobého přístupu k údajủm bez současné nebo budoucí nejistoty ohledně legálních práv či technické specifikace“. K tomu více viz Rozhodnutí ÚOHS ze dne 20. 3. 2012 (ÚOHS-R236/2011/VZ4006/2012/310/PMo).
} 


\subsubsection{KLÍČOVÁ ROZHODNUTÍ}

Použití otevřených a svobodných komponent představovalo jedno z klíčových rozhodnutí při přípravě a řešení projektu. $V$ dnešní době existuje nepřeberné množství používaných licencí, které které jsou veřejně svými provozovateli deklarovány jako open source, ${ }^{42}$ byt jsou $\mathrm{z}$ povahy věci v mnoha ohledech pro své uživatele vysoce omezující a ne vždy zcela transparentní. Pro naše potřeby musíme odlišovat „použití od „odvozeného díla“. Pokud je součástí našeho systému aplikační server X, jde o „použití“, protože výsledkem není aplikační server, ale celá aplikace. To samé platí u databází, případně knihoven. Všechny open source licence se vzdávají zodpovědnosti za škody kvůli nefunkčnosti. Vlivem poskytnutí softwaru zdarma je to očekávatelné. Bohužel, ani placené varianty neposkytují lepší podmínky; pouze slibují reakci na chybu, zpravidla avšak nikoli její opravu.

\subsubsection{JEDNOTLIVÉ POUŽITÉ LICENCE}

Užili jsme licence MIT, BSD, dovolující uživateli nakládat s projektem prakticky libovolně. Zakázáno je pouze distribuovat odvozený kód pod stejným jménem. Dále jsme užili licenci GPL, nejslavnější licenci, se kterou Richard Stallman založil celé hnutí Free Software \& Open Source. Použití je povolené, ale u odvozeného díla je vyžadováno šíření pod licencí GPL - jednou svobodný software musí zůstat svobodný. Nejvyšším požadavkem na takové dílo je povinnost poskytnout uživateli díla na požádání zdrojové kódy. Celá licence je vymyšlena jako konkurenční výhoda open source, přičemž GPL díla smí využívat GPL knihovny, zatímco uzavřené knihovny nikoliv, protože výrobce nechce poskytovat své zdrojové kódy. Software pod GPL licencí nepoužíváme jako součást aplikace, abychom neovlivňovali licenci

\footnotetext{
${ }^{41}$ Jedním $\mathrm{z}$ relativně standardních požadavků, podmiňujících využití těchto výhod, resp. souvisejících uživatelských oprávnění, je zpravidla zveřejnění zdrojového kódu (některé licence však ujednání o př́stupnosti zdrojového kódu neobsahují). K tomu více viz MYŠKA, M.; KYNCL, L.; POLČÁK, R.; ŠAVELKA, J.; SVIRÁKOVÁ, I. Veřejné licence v České republice. Verze 2.0. Brno: Masarykova univerzita, 2014, ISBN 978-80-210-7193-3, s. 76 a násl. Elektronická verze publikace je dostupná https://is.muni.cz/repo/1203341/Myska_et_al._-_Verejne_licence_2.0_-_online.pdf.

${ }^{42} \mathrm{~K}$ tomu více viz např. HARAŠTA, J. Google opět před Evropskou komisí - může být opensource proti soutěži? Obchodněprávní revue, 2016, č. 10, ISSN 1803-6554, s. 282.
} 
projektu. Využití GPL software například pro monitorování není vytváření odvozeného díla a tudíž neovlivňuje licenci projektu. Dále jsme užili licenci LGPL, mírnější formu GPL, používanou pro knihovny, kde autor chce umožnit svobodu dané knihovny i v uzavřeném díle. Klíčový požadavek je zachovat možnost uživateli cílového díla nahradit tuto knihovnu, např. opravenou nebo novou verzí. A samozřejmě na vyžádání poskytnout zdrojové kódy $\mathrm{k}$ této knihovně. Užili jsme též licenci CDDL, tedy licenci podobnou GPL, doplněnou ochranou proti softwarovým patentům. Konečně byla užita Apache Licence (ASL), velmi volná licence, dovolující libovolné použití. Zakázáno je pouze použití ochranných známek (trademark) jako označení identifikující samy sebe, své výrobky či další služby.

\subsection{DATABÁZE}

V oblasti databází existuje několik úspěšných projektů. Vybrali jsme PostgreSQL, ${ }^{43}$ především kvůli stabilitě, rychlosti, spolehlivosti, rozšǐritelnosti a v neposlední řadě i licence. Dalšími možnostmi bylo MySQL/MariaDb, které má výrazně slabší dotazovací jazyk a spolehlivost, alternativou byla i databáze Firebird. Licencí je PostgreSQL, podobná MIT a BSD.

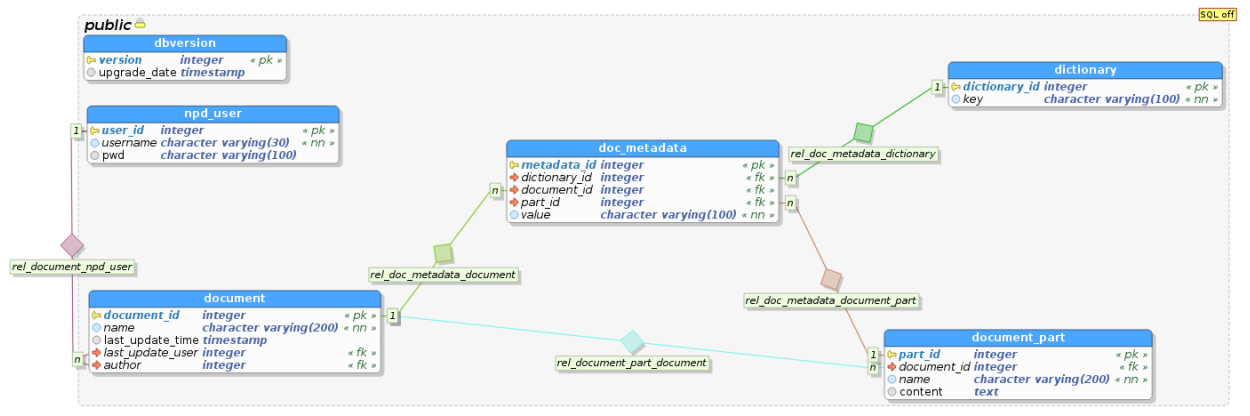

Obr. 16. Schématický náčrt databáze.

\subsection{APLIKAČNÍ SERVER}

Na serverovou stranu jsme použili řešení typické pro podnikové systémy, které kladou důraz na spolehlivost - platformu Java Enterprise Edition 7.

43 PostGreSQL [online]. [cit. 12.12.2017]. Dostupné z: https://www.postgresql.org/. 
Její široké použití zajištuje, že systém bude možné rozvíjet i po dlouhé době, kdy budou zcela určitě existovat podporované servery i programátoři se zkušeností s touto technologií. Z dostupných serverů jsme použili Glassfish, ${ }^{44}$ referenční implementaci od firmy Oracle. Do budoucna uvažujeme ještě o přechodu na server Payara s o něco lepší podporou komunity. Payara vznikla jako komunitní odnož (fork) Glassfishe s rychlejším vývojem, ošetřením bezpečnostních problémů a dalšími rozšířeními. Licence je CDDL a GPL. Alternativou je JBOSS od RedHat, nebo TomEE od Apache. $\mathrm{Na}$ aplikační server jsme nasadili dva druhy monitoringu. Jednak na úrovni systému (dostupnost a mailové upozornění při problémech ${ }^{45}$ ), jednak na úrovni Javy. Toto druhé sledování stavu aplikace zajištuje knihovna JavaMelody. ${ }^{46}$ Užítí JavaMelody nám dovoluje sledovat stav aplikace, využití paměti a nároky na výkon. Licence je Apache License 2.0.

\subsection{BEZPEČNOST - PŘEDSAZENÍ WEBOVÉHO SERVERU}

Aplikační server poskytuje potřebné služby, bohužel zaostává v bezpečnosti. Protože škála služeb nedovoluje dokonalé zabezpečení a nová ohrožení se v budoucnu určitě najdou, komunikaci s klientem zprostředkovává webový server, v našem případě nginx. ${ }^{47}$ Licence je 2-clause BSD license. Jde o typické nastavení tzv. reversní proxy. Kromě omezení bezpečnostních děr zprostředkovává webový server i HTTPS terminaci. Alternativou je Apache, který je mnohem více konfigurovatelný, ale o to složitější a přináší i vyšší payload.

\subsection{ULOŽENÍ DAT}

Data jsou uložena na fyzickém diskovém poli sestávajícím ze 4 fyzických disků v RAID 10 poli. Samotný virtualizační systém využívá jiné disky. Tím je zaručeno, že veškerý výkon disků je věnován pouze tomuto projektu.

\footnotetext{
${ }^{44}$ Glassfish [online]. [cit. 12.12.2017]. Dostupné z: https://javaee.github.io/glassfish/

45 Srov. oddíl Virtuální servery níže.

46 Javamelody [online]. [cit. 12.12.2017]. Dostupné z: https://github.com/javamelody/

47 Nginx [online]. [cit. 12.12.2017]. Dostupné z: http://nginx.org
} 


\subsection{VIRTUÁLNÍ SERVERY}

Projekt využívá možností virtualizace, v tomto konkrétním případě pomocí projektu KVM. Díky tomu bylo možné na jeden fyzický server (IBM Lenovo) nasadit čtyři virtuální stroje pro projekt Národní právní dědictví. Virtualizace se zde využívá především proto, že konfigurace fyzického serveru poskytuje výrazný nadbytek výkonu pro provoz jediného produkčního serveru. Výkon je tak rozdělen mezi více virtuálních serverů, které rozhodně netrpí nedostatkem prostředků; v tomto ohledu lze považovat virtualizaci (podobně jako cloudová řešení) za určitý aktuální světový trend. Ačkoliv se jedná o virtuální servery, všechny jsou pochopitelně monitorovány specializovaným softwarem. $\mathrm{V}$ našem případě jsme zvolili monitorovací systém Zabbix, který je open source, ale zároveň se řadí do třídy enterprise řešení. Dovoluje nám nejen monitorovat aktuální stav serverů, ale i inteligentně predikovat, jak se budou jednotlivé trendy vyvíjet do budoucnosti a tak i umožnit regulovat potřebné prostředky nebo např. dokoupit potřenou infrastrukturu před tím, než dojde $\mathrm{k}$ jejímu přetîžení.

\subsection{ZÁLOHOVÁNí}

Zálohování je vždy jedním z nejdůležitějších prvků systému. Soubory jsou denně zálohovány pomocí systému deduplikace, zajištujícího, že soubor je fyzicky zálohován pouze jednou, přičemž ve všech ostatních zálohách se jedná pouze o odkaz na tento soubor. Tím se dramaticky snižuje objem prostoru, který je pro zálohování potřebný. Databáze (produkční i pro Git tasky) je zálohována do také místopisně odděleného datacentra v Kanadě v blízkosti Montrealu (voleno z důvodu umístění záloh na jiný kontinent) čímž se urychluje možnost obnovy). 


\title{
PRÁVNÍK
}

ČASOPIS

\section{VĚNOVANÝ VĚDĚ PRÁVNÍ I STÁTNÍ,}

JEJŽ VYDẢVẢ

\author{
PRÁVNICKÁ JEDNOTA V PRAZE, \\ S PODPOROU ČESKÉ AKADEMIE PRO VĚDY, \\ SLOVESNOST A UMĚNi \\ ODPOVÊDNI REDAKTORI:

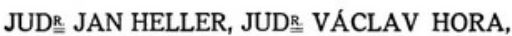 \\ JUD్ JOSEF LUKAS̆.
}

ROČNIKK LVIII.

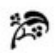

V PRAZE.
NAKLAD JEONOTY PRAVNICKE, - KNHTISKANNA DR. ED, GREGR A SYN V PRAZE
1919.

Obr. 17. Titulní stránka časopisu Právník z roku 1919.

\section{ZÁVĚRY}

V článku jsme ukázali výchozí situaci obtížné dostupnosti starší právní literatury a ukázali jsme také, jakým zpơsobem se zatím snažily tento problém řešit jiné projekty a iniciativy. Z jejich kritického zhodnocení vyrůstala koncepce projektu Národního právního dědictví. Ten představuje typově nový př́stup, který nechce být pouhou digitalizací, nýbrž cílí k vytvoření vysoce kvalitního právního informačního systému, splňujícího nejnáročnější vědecké požadavky, avšak umožňujícího také vyhledávání zjednodušené, pro běžného uživatele, stejně jako standardní služby kvalitních digitalizačních projektů, zahrnující možnost stahování dokumentů pro práci offline. 
Očekávané přínosy projektu Národní právní dědictví lze shrnout do několika okruhů. Prvním je vytvoření možnosti náročného vyhledávání v databázi a možnost analytické práce s textem. Tím se otevírají nové výzkumné i rešeršní možnosti.

Druhým okruhem přínosů jsou výhody, společné všem digitalizačním projektům - ubiquita, vzdálený př́istup, absence nutnosti střežit cenné originály při jejich užívání čtenáři, atd. V českých podmínkách, které jsou $\mathrm{v}$ řadě ohledů atypické, však tento okruh přínosů zároveň znamená také zásadní a konečné zacelení ztrát, které knihovny utrpěly povodněmi, v menší míře i krádežemi či jiným ničením knižního fondu (např. vytrháváním článků ze svázaných ročníků časopisů). Přestože jde o zacelení náhražkové, tento jeho charakter je vyvážen řadou výhod.

Třetím okruhem přínosů, který je ovšem důsledkem okruhu prvého a druhého, jsou zásadní přínosy společenské, přínosy v oblasti vybavenosti českých a slovenských právnických fakult a univerzit obecně. Dojde k pronikavému nastolení rovnosti v přístupu členů akademických obcí jednotlivých fakult a univerzit k historickým právním textům. Znamená to ukončení tragické nedovybavenosti fakultních knihoven - alespoň pokud jde o starší literaturu - a bude snad působit příznivým a hojivým účinkem proti některým vývojovým tendencím $\mathrm{v}$ českém vysokoškolském právnickém prostoru v uplynulém čtvrtstoletí (nedovybavenost knihoven, odkázanost fakult na sebe samé). ${ }^{48}$

Čtvrtým okruhem přínosů bude široké zpřístupnění historických právních informací pro potřebu soudů, státních i samosprávných úřadů a obecně i právních profesí. Široké otevření přístupu k historickým právním textům dalším odborným skupinám mimo právo (historické vědy, lingvistika, politická věda, hospodářské vědy) může také napomoci zvýšení mezioborového zohledňování historického práva a historické právní vědy jinými vědními obory. Znamená také nastolení rovnosti $\mathrm{v}$ přístupu $\mathrm{k}$ těmto textům mezi takzvanými centry a takzvanou periferií: tedy mezi velkými městy s důležitými historickými a vědeckými knihovnami (Praha, Brno, Olomouc)

${ }^{48}$ Podrobněji k tomu v tezích projektu, uvedených v článku v poznámce č. 2. 
a mezi ostatními knihovnami s historickým odborným knižním fondem nedostatečně vybavenými lokalitami v republice, resp. i kdekoli v zahraničí.

\section{SEZNAM LITERATURY}

\subsection{LITERATURA}

[1] CVRČEK, F.; DONÁT, J.; NOVÁK, F. Informační systém o čs. právních předpisech - CS Legsys. Právník. Praha: Ústav státu a práva AV ČR. 1991, č. 5, s. 456-465. ISSN 0231-6625.

[2] CVRČEK, F. Právní informatika. Praha; Plzeň: Aleš Čeněk, 2010, ISBN 978-80-87439-00-5, s. 35-38.

[3] HARAŠTA, J. Google opět před Evropskou komisí - může být open-source proti soutěži? Obchodněprávní revue, 2016, č. 10, ISSN 1803-6554, s. 282-285.

[4] KOBER, J. Mezi Clio a Justitií: psaní o starší právní vědě a návrat jedné antologie. Právník. Praha: Ústav státu a práva AV ČR. 149 (2010), č. 4, s. 419, 429-430. ISSN 0231-6625.

[5] KOBER, J.; MATEJKA, J. Právněhistorická databáze Národní právní dědictví. In: SUCHOŽA, J.; HUSÁR, J.; HUČKOVÁ, R. (ed.). Právo, obchod, ekonomika VII. Košice: Univerzita Pavla Jozefa Šafárika, Právnická fakulta, 2017, ISBN 978-80-8152-528-5, s. 225 a n.

[6] KORBEL, F.; MELZER, F. Společenské a právní základy zveřejňování judikatury a způsoby jeho realizace. Právní rozhledy, Praha: C. H. Beck, 2011, č. 9; s. 314-321. ISSN 1210-6410.

[7] MATEJKA, J. Internet jako objekt práva: hledání rovnováhy autonomie a soukromí. Praha: CZ.NIC, 2013, ISBN 978-80-904248-7-6, 256 s., Dostupné [online] z: https://knihy.nic.cz/files/nic/edice/jan_matejka_ijop.pdf

[8] MYŠKA, M.; KYNCL, L.; POLČÁK, R.; ŠAVELKA, J.; SVIRÁKOVÁ, I. Veřejné licence $v$ České republice. Verze 2.0. Brno: Masarykova univerzita, 2014, ISBN 978-80-210-7193-3, s. 76 a násl. Elektronická verze publikace je dostupná z: https://is.muni.cz/repo/1203341/Myska_et_al.__Verejne_licence_2.0_-_online.pdf

[9] MYŠKA, M.; Vybrané právní aspekty otevřeného přístupu k vědeckým informacím. Právní rozhledy, 2014, č. 18, s. 611-619. ISSN 1210-6410.

[10] RICHTER, T. Koho chléb jî̌s, toho píseň zpívej: konflikty vznikající při propojení právní praxe s právní teorií. Právník. Praha: Ústav státu a práva AV ČR, 2013, č. 2, s. 124-137. ISSN 0231-6625.

\subsection{SEZNAM ONLINE ZDROJŮ}

[11] Glassfish [online]. [cit. 12.12.2017]. Dostupné z: https://javaee.github.io/glassfish/

[12] Javamelody [online]. [cit. 12.12.2017]. Dostupné z: https://github.com/javamelody/

[13] Nginx [online]. [cit. 12.12.2017]. Dostupné z: http://nginx.org

[14] PostGreSQL [online]. [cit. 12.12.2017]. Dostupné z: https://www.postgresql.org/ 
[15] PRÁVNICKÁ FAKULTA MASARYKOVY UNIVERZITY. Moravská sbírka [online]. [cit. 15.11.2017]. Dostupné na: https://is.muni.cz/do/rect/el/estud/praf/ps09/dlibrary/

web/ms.html

[16] PRÁVNICKÁ FAKULTA MASARYKOVY UNIVERZITY. Říšský zákoník [online]. [cit. 15.11.2017]. Dostupné z: https://is.muni.cz/do/rect/el/estud/praf/ps09/dlibrary/

web/rs.html

[17] PRÁVNICKÁ FAKULTA MASARYKOVY UNIVERZITY. Digitální knihovna historického fondu [online]. [cit. 15.11.2017]. Dostupné z: https://library.law.muni.cz/content/cs/ezdroje/digitalni-knihovna/

[18] PRÁVNICKÁ FAKULTA MASARYKOVY UNIVERZITY. O projektu [online]. [cit. 23.12.2018]. Dostupné na: https://is.muni.cz/do/law/kat/kdsp/bibliografie/o_projektu.html

[19] PRÁVNICKÁ FAKULTA UNIVERZITY KARLOVY. Historická sbírka knihovny Právnické fakulty UK [online]. [cit. 12.11.2017]. Dostupné z: http://digitool.is.cuni.cz/R/Y2K1NAKRBSHAKP4RHCLK7XKVG4QFCNS485EJDNSMNN98RGIT8U-00097? func $=$ collectionsresult\&collection_id $=2847$

[20] ÚSTAV STÁTU A PRÁVA. Databáze [online]. [cit. 22.11.2017]. Dostupné na: https://www.ilaw.cas.cz/sluzby-on-line-knihovna/databaze.html

[21] ÚSTAV STÁTU A PRÁVA. Databáze CLAN [online]. [cit. 22.11.2017]. Dostupné z: https://data.ilaw.cas.cz/knihovna_vyhledavani.php

\subsection{CITACE ZDROJU゚ OBRÁZKŮ}

[22] Obr. 1. Neznámý autor. Vyobrazení Leopolda Heyrovského (zatím neveřejný přistup). In: Národní právní dědictví [online]. [vid. 20.09.2017]. Dostupné z: http://www.npd.cz

[23] Obr. 2. Sbírka nálezů Nejvyššího správního soudu ve věcech administrativních, pořádaná J. V. Bohuslavem, první svazek za léta 1918-1919, vydaný roku 1920. In: Národní právní dědictví [online]. [vid. 20.09.2017]. Dostupné z: http://www.npd.cz

[24] Obr. 3. Ukázka z rejstř́ku digitalizovaných parlamentních materiálů v Digitálním repozitáři PSP. In: Společná česko-slovenská digitální parlamentní knihovna [online]. [vid. 20.09.2017]. Dostupné z: https://www.psp.cz/eknih/1918ns/ps/rejstrik/vecny/h.htm

[25] Obr. 4. Základní rozhraní Moravské sbírky zákonů. In: Virtuální knihovna právních předpisů [online]. [vid. 20.09.2017]. Dostupné https://is.muni.cz/do/1499/el/estud/praf/ps09/dlibrary/web/ms.html

[26] Obr. 5. Příklad ročníku bez metadat (ročník 1854). In: Virtuální knihovna právních předpisů [online]. [vid. 20.09.2017]. Dostupné z: https://is.muni.cz/do/1499/el/estud/praf/ps09/dlibrary/web/ms.html

[27] Obr. 6. Základní rozhraní řišské sbírky zákonů. In: Virtuální knihovna právních předpisů [online]. [vid. 20.09.2017]. Dostupné z: https://is.muni.cz/do/1499/el/estud/praf/ps09/dlibrary/web/rs.html 
[28] Obr. 7. Ukázka vyhledávání v databázi CLAN (neveřejný př́stup). In: CLAN [online]. [vid. 20.09.2017]. Dostupné z: https://data.ilaw.cas.cz/knihovna_vyhledavani.php

[29] Obr. 8. Ukázka záznamu článku v databázi CLAN s knihovnicky zpracovanou anotací jeho obsahu (neveřejný př́stup). In: CLAN [online]. [vid. 20.09.2017]. Dostupné z: https://data.ilaw.cas.cz/knihovna_vyhledavani.php

[30] Obr. 9. Ukázka vyhledávání v Bibliografii vybraných právnických časopisů a sborníků. In: Bibliografie vybraných právnických časopisů a sborníků [online]. [vid. 20.09.2017]. Dostupné z: https://is.muni.cz/do/law/kat/kdsp/bibliografie/library.html.

[31] Obr. 10. Historické vyobrazení členů lichevních soudů z roku 1922 (zatím neveřejný přístup). In: Národní právní dědictví [online]. [vid. 20.09.2017]. Dostupné z: http://www.npd.cz

[32] Obr. 11. Př́klad plného textu článku: Mildschuhův Posudek návrhu zákona o účasti zaměstnanců na správě a čistém zisku podniků z Právníka 59 (1920) (zatím neveřejný přístup). In: Národní právní dědictví [online]. [vid. 20.09.2017]. Dostupné z: http://www.npd.cz.

[33] Obr. 12. Ukázka hesla z Všeobecného slovníku právního od F. X. Veselého z roku 1896 (zatím neveřejný přistup). In: Národní právní dědictví [online]. [vid. 20.09.2017]. Dostupné z: http://www.npd.cz

[34] Obr. 13. Celkový náhled na základní (jednoduchou) podobu vyhledávací masky databáze Národního právního dědictví (zatím neveřejný přistup). In: Národní právní dědictví [online]. [vid. 20.09.2017]. Dostupné z: http://www.npd.cz

[35] Obr. 14. Výpis výsledků vyhledávání v databázi Národního právního dědictví (zatím neveřejný př́stup). In: Národní právní dědictví [online]. [vid. 20.09.2017]. Dostupné z: http://www.npd.cz

[36] Obr. 15. Příklad plného textu soudního rozhodnutí: Váž. civ. 5.1923 - Rozhodnutí č. 2196 (zatím neveřejný prrístup). In: Národní právní dědictví [online]. [vid. 20.09.2017]. Dostupné z: http://www.npd.cz

[37] Obr. 16. Schématický náčrt databáze. Vytvořeno autory textu, dosud nepublikováno.

[38] Obr. 17. Titulní stránka časopisu Právník z roku 1919 (zatím neveřejný přístup). In: Národní právní dědictví [online]. [vid. 20.09.2017]. Dostupné z: http://www.npd.cz

Toto dílo lze užít v souladu s licenčními podmínkami Creative Commons BY-SA 4.0 International (http://creativecommons.org/licenses/by-sa/4.0/legalcode). 